\section{Ankara Üniversitesi Eğitim Bilimleri \\ Fakültesi Özel Eğitim Dergisi}

2021, 22(4), 799-825
ARAŞTIRMA

Gönderim Tarihi: 23.04 .20

Kabul Tarihi: 05.02.21

Erken Görünüm: 22.02.21

\title{
Otizm Spektrum Bozukluğu ve Zihinsel Yetersizliği Olan Bireylerin Ebeveynlerinin Yaşam Doyumu ve Aile Yılmazlık Düzeylerinin İncelenmesi
}

\author{
Mehmet Yavuz ${ }^{\text {iD } 1}$
}

\author{
Özlem Gümüşkaya ${ }^{2} 2$
}

$\ddot{\text { Ozz }}$

Giriş: Bu araştırmada otizm spektrum bozukluğu (OSB), zihinsel yetersizliği (ZY) olan çocukların ebeveynlerinin yaşam doyumu ve aile yılmazlık düzeyleri incelenmiştir.

Yöntem: Araştırmada ilişkisel tarama modeli kullanılmıştır. Araştırmanın katılımcılarını İzmir ve Bursa illerinden 309 ebeveyn oluşturmaktadır. Veriler Aile Yılmazlık Ölçeği ve Yaşam Doyumu Ölçeği kullanılarak elde edilmiştir. Verilerin analizinde t-testi, ANOVA, Tukey HSD Testi ve Pearson korelasyon analizi kullanılmıştır.

Bulgular: Ebeveynlerin yaşam doyumları ile ilgili değişkenlerle ilgili bulgular, annelerin, genç ebeveynlerin, geliri yüksek olanların, eğitim düzeyi yüksek olanların, çocukları ZY olan ebeveynlerin yaşam doyum düzeyleri karşılaştırıldıkları gruplara göre daha yüksek olduğunu göstermiştir. Aile yılmazlık düzeyleri, cinsiyette genel ölçek puanında, mücadelecilik, yaşama bağlılık ve kendini kontrol alt boyutlarında annelerin, öz-yetkinlik alt boyutunda genç ebeveynlerin, öz-yetkinlik alt boyutunda gelir düzeyi yüksek olanların, mücadelecilik alt boyutunda eğitim düzeyi yüksek olanların, çocuklarının yetersizlik türü değişkeninde genel ölçek puanında, mücadelecilik, öz-yetkinlik ve yaşama bağlılık alt boyutlarında ZY olan çocukların ebeveynlerinin lehine anlamlı farklılıklar gözlenmiştir. Yaşam doyumu ile aile yılmazlığı ve tüm alt boyutları arasında pozitif ilişki bulunmaktadır.

Tartışma: Çalışmanın bulguları alanyazın çerçevesinde tartışılmıştır. Araştırma sonucuna göre yaşam doyumu yüksek olan bireylerin aile yılmazlık düzeylerinin de yüksek olduğu gözlenmiştir. Yaşam doyum düzeyi yüksek olan bireyler hayata daha olumlu yönleriyle bakmakta, daha az stres yaşamakta ve karşılaştıkları sorunları daha kolay aşabilmektedirler.

Anahtar sözcükler: Aile, yaşam doyumu, aile yılmazlığı, otizm spektrum bozukluğu, zihinsel yetersizlik.

Atıf için: Yavuz, M., \& Gümüşkaya, Ö. (2021). Otizm spektrum bozukluğu ve zihinsel yetersizliği olan bireylerin ebeveynlerinin yaşam doyumu ve aile yılmazlık düzeylerinin incelenmesi. Ankara Üniversitesi Eğitim $\begin{array}{llllll}\text { Bilimleri Fakültesi Özel } & \text { Eğitim }\end{array}$ https://doi.org/10.21565/ozelegitimdergisi.726030

\footnotetext{
${ }^{1}$ Sorumlu Yazar: Dr. Öğr. Üyesi, Trakya Üniversitesi, E-posta: mehmetyavuz23@gmail.com, https://orcid.org/0000-00030762-1611

2Dr. Öğr. Üyesi, Sakarya Üniversitesi, E-posta: okaya@ sakarya.edu.tr, https://orcid.org/0000-0002-1626-7637
} 


\section{Giriş}

Yetersizliği olan bir çocuğun aileye katılımı ailenin yaşamını önemli bir ölçüde etkilemekte ve buna bağlı olarak ailenin yaşam şeklini önemli ölçüde değiştirmektedir (Akkök, 2003; Ohaeri, 2003; Walsh, 2006). Yetersizliği olan bir çocuğun aileye katılımı ailenin yaşam şeklini değiştirmenin yanında özellikle ebeveynlerin psikolojisini önemli ölçüde etkilemektedir. Bu durumun birçok sebebi bulunmaktadır. Öncelikle ebeveynlerin doğacak çocuklarının sağlıklı olmasını beklerken, çocuğun sağlıklı doğmaması sebebiyle beklenmedik bir durumla karşılaşmış olmaları hayal kırıklığı yaşamalarına neden olmaktadır (Cavkaytar \& Özen, 2010). Buna ek olarak, bu yeni durumu çevrelerine açıklamada yetersiz kalmaları ebeveynlerin psikolojik durumunu önemli ölçüde etkilemektedir (Akkök, 2003; Cavkaytar \& Özen, 2010). Ayrıca, ebeveynlerin, çocuğun yetersizliği hakkında bilgi eksikliklerinin bulunması ve çocuğun ek sağlık sorunlarının olması da psikolojik olarak iyi olma durumlarını olumsuz etkilemektedir (Cavkaytar \& Özen, 2010; Saunders vd., 2015). Çünkü sağlık sorunları, aile bütçesine ek yük getirmekte ve aile sürekli hastaneye gitmek, birçok farklı uzmanla etkileşime girmek zorunda kalmaktadır. Bu tür sorunlar ebeveynlerin birbirlerine zaman ayıramamasına ve sosyal çevreden soyutlanmasına da neden olmaktadır (Patterson, 2002; Schaaf vd., 2011). Bahsedilen tüm sorunlar, zaman içinde ebeveynlerde stres (Darling vd., 2012; Kaner vd., 2011; Ohaeri, 2003; Patterson, 2002; Seltzer vd., 2001), kayg1 (Kaner, 2009), düşük benlik saygıs1 (Girli vd., 1998), daha fazla sağlik sorununa ve depresyona sebep olabilmektedir (Roach vd., 1999). Bu durumlar ebeveynlerin günlük yaşam etkinliklerini sürdürmesinde ve bireyler arası ilişkilerde sorunlar yaşamasına neden olabilmektedir. Ayrıca ebeveynler sosyal ilişkilerde geri çekilme, içe kapanma ve savunmasızlık gibi problemler yaşayabilmektedirler (Kaner, 2004). Küçüker'e (1993) göre bunlar da ebeveynlerin çocuklarıyla iletişimde problem yaşamasına, çocukları için gerçekçi olmayan amaçlar belirlemelerine, çocuğun ihtiyaçlarını görmezden gelmelerine ve hatta çocuğu reddetme tutumu sergilemelerine neden olabilmektedir.

Ebeveynlerin yaşadığı psikolojik sorunlar yaşaması çocuğun yaşı, yetersizlik türü ve düzeyi, çocuğun ihtiyaçlarını karşılayabilme yeterliliklerine göre değişebilmektedir (Kaner, 2009; Patterson, 2002). Örneğin, diğer gelişimsel yetersizliklerle karşılaştırıldığında otizm spektrum bozukluğu (OSB) olan çocukların ebeveynlerinin daha fazla strese maruz kalındığı belirtilmektedir (Hayes \& Watson, 2013; Marcus vd., 2005). Bunların yanında, çocuğun geleceği için duyulan kaygı, yakın çevrenin olumsuz tutumları da ebeveynlerin stres düzeyini olumsuz etkilemektedir. Tüm bu sorunlara maruz kalmak ebeveynlerin çocuğun yetersizliğini kabul etmelerini zorlaştırmaktadır (Cavkaytar \& Özen, 2010). Ebeveynlerin uzun süreli stres yaşamaları aile ilişkilerini olumsuz etkileyebilmekte (Akkök, 2003; Walsh, 2006), eşler birbirleriyle sorunlar yaşayabilmekte ve hatta boşanabilmektedir (Sloper \& Turner, 1993).

Ebeveynlerin bu sorunlarla başa çıkma davranışlarını etkileyen çeşitli değişkenler bulunmaktadır. Bu değişkenlerden bazıları, ailenin ekonomik durumu, aile üyelerinin birbirine bağlılığı, çevreden aldıkları sosyal destek olarak sıralanabilir (Turnbull vd., 2006). Bunların yanında ebeveynlerin bu sorunlarla başa çıkmalarını etkileyen önemli değişkenlerden biri de ebeveynlerin yılmazlık düzeyleridir (Altındağ-Kumaş \& Sümer, 2019; Olsson vd., 2003; Patterson, 2002). Yılmazlık (resilience), bireyin zor veya aniden oluşan yaşam koşullarıyla başa çıkma yollarını bulmasıdır (Ahern vd., 2006). Aile yılmazlığ üstesinden gelebilme ve yeniden dengeli duruma dönme yeteneğidir (Patterson, 2002). Yılmazlık, bireyin günlük hayata uyum sağlamasını ve stresli bir durumla karşılaştığında bu sorunlarla başa çıkmasını sağlamaktadır. Aile yılmazlığını, ailenin sosyal destek kaynağının güçlü olması (Bristol, 1984), ailenin birlikte olması ve maneviyat gücü gibi değişkenler de etkilemektedir (Bayat, 2007). Yılmazlık düzeyi yüksek olan ebeveynler daha az depresif davranışlar sergilemekte, evliliklerinde daha mutlu olmakta (Bristol, 1984) ve yetersizliği olan çocuklarını daha kolay kabullenmektedirler (Bayat, 2007; Bristol, 1984). Bunun yanı sıra, stresli olaylar karşısında yılgınlık yaşamamakta, kolayca toparlanmakta ve durumdan daha güçlü çıkmaktadırlar (Henderson \& Milstein, 1996). Patterson'a (2002) göre yılmazlık düzeyi yüksek ebeveynler yetersizliği olan çocuğun doğumuyla oluşan stres ile kolayca başa çıkmakta ve hayatlarını normal bir şekilde devam ettirmektedirler.

Ebeveynlerin yaşadıkları stres, depresyon gibi sorunlarla baş etmelerini sağlayan bir diğer değişken de ebeveynlerin yaşam doyumu düzeyleridir. Yaşam doyumu, kişinin yaşamına dair sahip olduğu genel yargı ve değerlendirmeleridir (Diener, 1985). Yaşam doyumu, bireyin tüm yaşamını bireysel olarak değerlendirmesini ifade etmekte ve tüm yaşamından, memnuniyeti moral durumu gibi psikolojik özellikler açısından ne kadar memnun olduğu ile ilişkilidir (Vara, 1999). Yaşam doyumu yüksek olan bireyler ılımlı, olumlu arzuları olan, zeki, sağlıklı (Sirgy vd., 2006), mutlu, sosyal hayata daha açık, sorunlar karşısında daha dayanıklı ve uygun tepkiler verebilen, intihar etme gibi düşüncelerinden uzak, bireyler arası ilişkileri yüksek, evlilik yaşantılarında sorun yaşamayan ve evlilikte oluşan sorunlarla kolayca başa çıkan bireylerdir (Sirgy vd., 2006). Özet bir ifade ile yaşam 
doyumu insana pozitif duygular katmakta ve yaşam doyumu yüksek bireylerin stres ve üzüntüden uzak yaşamaları kolaylaşmaktadır (Steger vd., 2006).

Alanyazınında, çeşitli yetersizlik gruplarından gelen bireylerin ebeveynlerinin yılmazlık düzeylerini ve yaşam doyumların ilgili çeşitli araştırmalara rastlanmaktadır. Heiman (2002) zihin yetersizliği (ZY), fiziksel yetersizliği (FY) ve öğrenme güçlüğü olan, Lloyd ve Hastings (2009), Bayraklı (2010) ve Kaner ve diğgerleri (2011) ZY olan ve olmayan, Plumb (2011) ve Turan (2017) OSB olan, McConnell ve diğerleri (2014) OSB, ZY, serabral palsisi ve diğer yetersizlik grubunda olan, Kumbasar (2016) işitme yetersizliği ve normal gelişim gösteren çocukların, Kadı (2016) çoklu yetersizliği olan, çocukların ebeveynlerinin yılmazlık düzeylerini incelemişlerdir. Bunların yanında Sloper ve diğerleri (1991) Down Sendromu olan, Akandere vd., (2009) ZY ve FY olan, Gülaldı (2010) serebral palsisi ve OSB olan, Sarıkaya (2011) ve Avşaroğlu ve Okutan (2018) ZY olan, Darling ve diğerleri (2012) yetersizliği olan çocuklar, Kantar (2014) OSB, ZY, bedensel yetersizliği ve down sendromu olan, Huang ve arkadaşları (2014) gelişimsel geriliği olan ve olmayan, Cho ve Kahng (2015) OSB ve ZY olan, Yavuz (2016) normal gelişim gösteren ve ZY olan, Çattık ve Aksoy (2018) OSB, ZY ve diğer gelişimsel yetersizliği olan çocukların ebeveynlerinin yaşam doyum düzeylerini incelemiş̧lerdir. Yetersizliği olan çocukların aile yılmazlığı ile yaşam doyumları arasında ilişkiyi inceleyen sınırlı sayıda araştırmaya ulaşılmıştır. Palancı (2018) ve Openshaw (2011) yetersizliği olan bireylerin yaşam doyumu ile aile yılmazlığı arasında ilişkiyi inceledikleri araştırmalarında pozitif yönlü güçlü ilişki gözlemlemişlerdir. Demiray (2019) ise özel gereksinimli çocukların ebeveynlerinin yaşam kalitesi ile aile yılmazlığı arasında pozitif yönlü güçlü ilişki tespit etmişlerdir.

OSB ve ZY olan bireylerin ailelerinin yaşam doyumu ve yılmazlık ilişkisine dair ülkemizde sınırlı sayıda araştırma bulunmaktadır (Demiray, 2019; Palanc1, 2018). Bu nedenle, bu araştırma, aile stresini olumsuz olarak en çok etkileyen gelişimsel yetersizliklerden olan OSB ve ZY olan çocukların ebeveynlerinin yaşam doyumu ve aile yılmazlık düzeyleri hakkında konuya ilişkin eksikliği gidermek amacıyla önemlidir. Ayrıca bu bilgiler ışı̆̆ında ebeveynlerin yaşam doyumunu ve dolayısıyla yılmazlık düzeylerini arttırmak için ebeveynlere verilebilecek eğitim ve destek hizmetlerinin düzenlenmesinde yol gösterici olması açısından önemlidir. Ayrıca, bu araştırmanın OSB ve ZY olan çocukların eğitimiyle ilgili alınacak kararlara yön vermesi açısından da yararlı olacağı düşünülmektedir. Ek olarak bu araştırmanın, OSB ve ZY olan çocukların ebeveynleriyle yapılacak ilerideki çalışmalara veri sağlaması açısından da önemli olduğu düşünülmektedir. Söz konusu nedenlerle, bu araştırmada OSB ve ZY olan çocukların ebeveynlerinin yaşam doyumu ve aile yılmazlı̆̆ düzeylerinin incelenmesi amaçlanmıştır. Bu amaçla aşağıdaki sorulara cevaplar aranmışıı:

1. Ebeveynlerin yaşam doyum ve aile yılmazlık düzeyleri cinsiyet, yaş, gelir düzeyleri, eğitim düzeyi ve çocukların yetersizlik türü değişkenleri açısından anlamlı farklılık göstermekte midir?

2. Ebeveynlerin aile yılmazlık düzeyleri ile yaşam doyum düzeyleri arasında bir ilişki var mıdır?

\section{Yöntem}

Bu bölümde araştırma modeli, çalışma grubu, veri toplama araçları, verilerin toplanması ve verilerin analizine yer verilmiştir.

\section{Araștırma Modeli}

$\mathrm{Bu}$ araştırmada, OSB ve ZY olan çocukların ebeveynlerinin yaşam doyum ve yılmazlık düzeylerinin incelenmesi amaçlanmıştır. Bu sebeple araştırmada ilişkisel tarama modeli kullanılmıştır. İliş̧isel tarama modeli iki ya da daha çok sayıdaki değişken arasında birlikte değişim varlığını ve/veya derecesini belirlemeyi amaçlayan araştırma modelidir (Karasar, 2012).

\section{Çalışma Grubu}

Araştırmanın katılımcıları 2019-2020 eğitim-öğretim yılında İzmir ve Bursa illerinde bulunan 15 Özel Eğitim ve Rehabilitasyon Merkezine (ÖERM) devam eden ve yetersizliği olan çocukların 309 ebeveyninden oluşmaktadır. Katılımcılara ait demografik bilgiler Tablo 1'de sunulmuştur. 
Tablo 1

Araştırmaya Katılan Ebeveynlere Ait Demografik Bilgileri

\begin{tabular}{|c|c|c|c|c|c|}
\hline Ebeveyn cinsiyeti & $n$ & $\%$ & Çocuğun yetersizlik türüa & $n$ & $\%$ \\
\hline Erkek & 122 & 39.5 & ZY & 139 & 44.98 \\
\hline Kadın & 187 & 60.5 & OSB & 170 & 55.02 \\
\hline Toplam & 309 & & Toplam & 309 & 100 \\
\hline Ebeveyn yaş1 & & & Ebeveyn eğitim düzeyi & & \\
\hline 30 yaş altı & 42 & 13.59 & İlköğretim & 86 & 27.8 \\
\hline $31-40$ yaş arası & 69 & 22.33 & Ortaöğretim & 79 & 25.6 \\
\hline $41-50$ yaş arası & 107 & 34.63 & Lisans & 80 & 25.9 \\
\hline 51 ve üstü & 91 & 29.45 & Lisansüstü & 64 & 20.7 \\
\hline Toplam & 309 & 100 & Toplam & 309 & 100 \\
\hline \multicolumn{6}{|l|}{ Ebeveyn gelir düzeyi } \\
\hline 2500 ve alt 1 & 88 & 28.5 & & & \\
\hline $2501-3500$ & 105 & 34.0 & & & \\
\hline $3501-4500$ & 61 & 19.7 & & & \\
\hline $4501-5500$ & 30 & 9.7 & & & \\
\hline 5501 ve üstü & 25 & 8.1 & & & \\
\hline Toplam & 309 & 100 & & & \\
\hline
\end{tabular}

${ }^{\text {aZY }}=$ zihin yetersizliği; OSB = otizm spektrum bozukluğu.

\section{Veri Toplama Araçları}

\section{Demografik Bilgi Formu}

Demografik bilgi formunda ebeveynlerin cinsiyeti, yaşı, gelir düzeyi, eğitim düzeyi ve çocuklarının yetersizlik türüne ilişkin sorular bulunmaktadır.

\section{Aile Yılmazlı Ölçeği (AYÖ)}

Aile Yılmazlık Ölçeği (AYÖ), Kaner ve Bayraklı (2010) tarafından anne-babaların yılmazlık algısını değerlendirmek amacıyla geliştirilmiştir. Ölçeğin geliştirilmesine özel eğitim kurumlarına devam eden 105 çocuğun ebeveyni ile normal gelişim gösteren 419 çocuğun ebeveynleri olmak üzere toplam 504 ebeveyn araştırmaya katılmıştır. İlk olarak 87 maddelik taslak ebeveynlere uygulanmıştır. Daha sonra geçerlilik çalışması için açımlayıcı faktör analizi, doğrulayıcı faktör analizi, madde-toplam korelasyonu, alt ölçekler arası korelasyon uygulanmıştır. Bunların yanında Beck Depresyon Envanteri, Öğrenilmiş Güçlülük Ölçeği ve Ana-Babalık Yetkinliği Ölçeği ile AYÖ’nün korelasyonlarına bakılmıștır. Güvenirlilik için ise Cronbach alfa, Spearman-Brown iki yarı güvenirlik ve test-tekrar test güvenirlik katsayılarına bakılmıştır. Ölçek toplam 37 maddeden ve Mücadelecilik (17 madde), Yaşama Bağlllık (8 madde), Öz-yetkinlik (9 madde) ve Kontrol (3 madde) olmak üzere dört alt ölçekten oluşmaktadır. Beşli likert tipindeki ölçeğin maddeleri (1) beni hiç tanımlamıyor, (2) beni biraz tanımlıyor (3) beni orta düzeyde tanımlıyor (4) beni iyi tanımlıyor, (5) beni çok iyi tanımlıyor şeklinde puanlanmaktadır. Ölçek alt ölçeklerinden yüksek puan almak yılmazlık düzeyinin yüksek olduğu anlamıma gelirken düşük puan almak yılmazlığın düşük olduğu şeklinde yorumlanmaktadır. AYÖ'nün Cronbach alfa katsayıları 0.54-0.91; test-tekrar test güvenirlik değerleri ise 0.33-0.80 arasında değişmekte olup, bu değerlerin tümü anlamlıdır. Bu araştırmanın Cronbach Alpha katsayısı 0.96 bulunmuştur.

\section{Yaşam Doyumu Ölçeği (YDö)}

Yaşam Doyumu Ölçeği (YDÖ), Diener ve diğerleri (1985) tarafından geliştirilmiş ve Dağlı ve Baysal (2016) tarafından Türkçeye uyarlanıp geçerlik güvenirlik çalışması yapılmıştır. Ölçeğin uyarlama çalışması için öncelikle Türkçeye çevrilmiş ve daha sonra ise dil ve içerik bakımından ölçme ve değerlendirme uzmanlarından görüş alınmıştır. Ölçekte uzmanların önerilerine göre değişiklikler yapılmıştır. Ölçeğin Türkçe formu ile İngilizce formunun dilsel eşitlik belirlemek için iki hafta arayla bir grup öğretmene uygulanmıştır. İki ölçek arasındaki puanı test etmek amacıyla Pearson Momentler Çarpımı Korelasyon Katsayısı hesaplanmış ve 0.92 olduğu gözlenmiştir. Böylelikle İngilizce ve Türkçe ölçek arasında yüksek düzeyde, pozitif ve anlamlı bir ilişki olduğu görülmüştür. Dil eşdeğerliği test edilen ölçek, Diyarbakır'da resmi ilkokullarda çalışmakta olan 200 öğretmene uygulanmıştır. Ölçeğin Cronbach Alpha katsayısı 0.88 ve test-tekrar test güvenirliği ise 0.97 olarak bulunmuştur. Orijinali beş maddeden oluşan ve beşli likert tipi olan ölçek, geçerlik-güvenirlik çalışması sonucunda yine benzer şekilde beş maddede, beşli likert ve tek boyutlu şekilde oluşturulmuştur. Bu araştırmanın Cronbach Alpha katsayısı 0.89 bulunmuştur. 


\section{Verilerin Toplanması}

Veriler İzmir ve Bursa illerinde özel özel eğitim ve rehabilitasyon merkezlerine kayıtlı yetersizliği olan bireylerin ebeveynlerinden toplanmıştır. Verilerin toplanması için toplam 12 özel özel eğitim ve rehabilitasyon merkezleri ziyaret edilmiş̧ir. Ebeveynlerle yüz yüze görüşme imkanı varsa ölçekler elden verilmiştir. Yüz yüze görüşme imkanı yoksa ölçekler kurum servisleriyle ailelere gönderilmiştir. Ölçekler hakkında açıklamaya ihtiyaç ailelere telefonla görüşülmüş ve araştırmanın önemi anlatılmıştır. Araştırmaya gönüllü olan ebeveynlere yüz yüze veya telefonla ölçekleri nasıl dolduracakları konusunda bilgi sunulmuştur. Katılımcılardan çocuklarında sadece ZE ve OSB olanlar araştırmaya dahil edilmiştir. Ebeveynlerin bir kısmına ölçekler kurum servisleriyle evlerine gönderilmiş, bir kısmına ise elden sunulmuştur. Velilere toplamda 800 adet ölçek gönderilmiş, 356 ölçek geri gelmiştir. Yapılan incelemeler sonucunda 47 ölçeğin hatalı veya eksik doldurulduğu görüşmüş ve verilerin analizi 309 ölçek üzerinde gerçekleştirilmiştir.

\section{Verilerin Analizi}

Verilerin analizi için IBM SPSS 24.0 paket programı kullanılmıştır. Öncelikle verilere normallik testi uygulanmıştır. Büyüköztürk'e (2014) göre verilerde normal dağılımı incelenirken veri sayısı 50'den küçükse Shapiro-Wilks, 50'den büyükse Kolmogorov-Simirnov testleri kullanılmalıdır. Bu nedenle veri sayısı 50'den fazla olduğunda dolayı Kolmogorov-Simirnov testi kullanılmıştır. AYÖ (sig: 085; $p>.05$ ) ve YDÖ (sig: 072; $p>$.05) Kolmogorov-Simirnov testi sonuçlarına göre verilerin normal dağıldığı gözlenmiştir. Bunun yanında basıklık ve çarpıklık değerlerine bakılmıştır. Tabachnick ve Fidell (2013) göre basıklık ve çarpıklık değerleri +1.5 ile -1.5 aralığında olursa normal dağılım göstermektedir. Bu araştırmanın AYÖ'de basıklık $(-0.272)$ ve çarpıklık $(-0.526)$ YDÖ'de ise basıklık (-0.071) ve çarpıklık (-0.041) değerleri de verilerin normal dağılım gösterdiği gözlenmiştir. $\mathrm{Bu}$ nedenle verilerin Parametrik testler kullanılarak analiz edilmesine karar verilmiştir. Verilerin analizinde betimsel istatistikler, bağımsız örneklem $t$ testi, tek yönlü ANOVA testi ve Tukey HSD Testi kullanılmıştır. Aile Yılmazlığı ile Yaşam Doyumu arasındaki ilişkiyi incelemek için ise Pearson korelasyon analizi yapılmıştır.

\section{Bulgular}

Bu bölümde, yaşam doyumu ve aile yılmazlık düzeylerinin cinsiyet, yaş, gelir düzeyi, eğitim düzeyi ve çocukların yetersizlik türüne ilişkin verilerin analizine ve yaşam doyumu ve aile yılmazlık arasındaki ilişki analizine yer verilmiştir. Cinsiyet değişkenine göre ebeveynlerin yaşam doyum düzeylerinin bağımsız gruplar $t$ testi sonuçları Tablo 2'de verilmiştir.

\section{Tablo 2}

Cinsiyet Değişkenine Göre Ebeveynlerin Yaşam Doyum Düzeylerinin Bağımsız Gruplar t Testi Sonuçları

\begin{tabular}{lcccccc}
\hline & Cinsiyet & $n$ & $\bar{X}$ & $S S$ & $t$ & $p$ \\
\hline \multirow{2}{*}{ Yaşam doyumu } & Anne & 122 & 3.24 & .96 & \multirow{2}{*}{2.62} & .009 \\
& Baba & 187 & 2.94 & .99 & & \\
\end{tabular}

Tablo 2'de görüldüğ̈̈ gibi anne ve babaların yaşam doyum düzeyleri arasında istatistiksel olarak anlamlı fark bulunmaktadır $(t(308)=2.62, p<.05)$. Bu anlamlı farklılık annelerin yaşam doyumu düzeylerinin babaların yaşam doyum düzeylerinden daha yüksek olduğunu göstermektedir. Yaş değişkenine göre ebeveynlerin yaşam doyum düzeylerinin ANOVA sonuçları Tablo 3 'te verilmiştir.

Tablo 3

Yaş Değişkenine Göre Ebeveynlerin Yaşam Doyum Düzeylerinin ANOVA Sonuçları

\begin{tabular}{clccccc}
\hline & \multicolumn{1}{c}{ Yaş } & $n$ & $\bar{X}$ & $S S$ & $F$ & $p$ \\
\hline & 30 yaş altı & 42 & 3.61 & .92 & & \\
Yaşam doyumu & 31-40 yaş arası & 69 & 2.93 & .99 & \multirow{2}{*}{8.19} & .000 \\
& 41-50 yaş arası & 107 & 3.17 & .90 & & \\
& 51 yaş ve üstü & 91 & 2.78 & 1.00 & & \\
\hline
\end{tabular}

Tablo 3'te görüldüğü gibi ebeveynlerin yaşam doyum düzeylerinin yaş değişkeni açısından farklılaşıp farklılaşmadığını belirlemek için yapılan ANOVA sonucunda yaşlar arasında anlamlı bir fark olduğu görülmektedir $(F(3,305)=8.19, p<.05)$. Bu anlamlı farklılığın hangi yaş aralığındaki ebeveynler arasında olduğunu belirlemek için Tukey HSD testi yapılmıştır. Bu analizin sonuçlarında 30 yaş altı $(\bar{X}=3.61)$ ile 31-40 yaş arası $(\bar{X}=2.93)$ ebeveynler karşılaştırıldığında 30 yaş altı ebeveynlerin yaşam doyum düzeylerinin anlamlı düzeyde yüksek, 30 yaş altı $(\bar{X}=3.61)$ ve 51 ve üstü yaş arasındaki ebeveynler karşılaş̧ırıldığında $(\bar{X}=2.78)$ yine 30 yaş altı ebeveynlerin yaşam doyum düzeylerinin anlamlı düzeyde yüksek, $41-50$ yaş arası $(\bar{X}=3.17)$ ile 51 ve 
üstü yaş arasındaki ebeveynlerin karşılaştırılmasında $(\bar{X}=2.78)$ 41-50 yaş arasında olan ebeveynlerin yaşam doyum düzeylerinin anlamlı düzeyde yüksek olduğu sonucuna ulaşılmıştır. Buna karşın diğer yaş grupları arasında yaşam doyum düzeyleri açısından anlamlı bir fark gözlenmemiştir. Gelir düzeyi değişkenine göre ebeveynlerin yaşam doyum düzeylerinin ANOVA sonuçları Tablo 4'te verilmiştir.

\section{Tablo 4}

Gelir Düzeyi Değişkenine Göre Ebeveynlerin Yaşam Doyum Düzeylerinin ANOVA Sonuçları

\begin{tabular}{clccccc}
\hline & \multicolumn{1}{c}{ Gelir düzeyi } & $n$ & $\bar{X}$ & $S S$ & $F$ & $p$ \\
\hline & 2500 TL ve altı & 88 & 2.78 & 1.00 & & \\
Yaşam doyumu & 2501-3500 TL aras1 & 105 & 2.86 & 1.03 & & \\
& 3501-4500 TL aras1 & 61 & 3.52 & .59 & 8.89 & .000 \\
& 4501-5500 TL aras1 & 30 & 3.51 & .87 & & \\
& 5000 TL ve üzeri & 25 & 3.25 & 1.08 & & \\
\hline
\end{tabular}

Tablo 4'te görüldüğg̈ gibi ebeveynlerin yaşam doyumu düzeylerinin gelir düzeyi değişkenine göre farklılaşıp farklılaşmadığını belirlemek için yapılan ANOVA sonuçları gelir düzeyleri arasında anlamlı bir fark olduğunu göstermiştir $(F(4,304)=8.89, p<.05)$. Bu anlamlı farklılığın hangi gelir düzeyine sahip ebeveynler arasında olduğunu belirlemek için yapılan Tukey HSD testi sonuçları $2500 \mathrm{TL}$ ve altında $(\bar{X}=2.78)$ ve 2501-3500 $\mathrm{TL}(\bar{X}=2.86)$ arasinda gelire sahip olanların $3501-4500 \mathrm{TL}(\bar{X}=3.52)$ ve $4501-5500 \mathrm{TL}(\bar{X}=3.51)$ arasinda gelire sahip olan ebeveynlerden anlamlı derecede daha düşük yaşam düzeyine sahip olduklarını göstermiş̧tir. Farklı bir ifade ile gelir düzeyi düştükçe yaşam doyumu da düşmektedir. Buna karşın diğer gelir düzeyleri arasında yaşam doyum düzeyleri açısından anlamlı bir fark gözlenmemiştir. Eğitim düzeyine göre ebeveynlerin yaşam doyum düzeylerinin ANOVA sonuçları Tablo 5'te verilmiştir.

Tablo 5

Ebeveyn Düzeyine Göre Ebeveynlerin Yaşam Doyum Düzeylerinin ANOVA Sonuçları

\begin{tabular}{lcccccc}
\hline & Eğitim durumu & $n$ & $\bar{X}$ & $S S$ & $F$ & $p$ \\
\hline \multirow{4}{*}{ Yaşam doyumu } & İlköğretim & 86 & 2.91 & 1.11 & & \\
& Ortaöğretim & 79 & 3.10 & 1.06 & 3.11 & .027 \\
& Lisans & 80 & 2.95 & 1.01 & & \\
\hline
\end{tabular}

Tablo 5’te görüldüğü gibi ebeveynlerin yaşam doyum düzeyleri eğitim düzeyi değişkeni açısından incelendiğinde anlamlı bir fark olduğu görülmüştür $(F(3,305)=3.1, p<.05)$. Bu anlamlı farklılığın hangi eğitim düzeyine sahip olan ebeveynler arasında olduğunu belirlemek için yapılan Tukey HSD testi sonuçları, ilköğretim $(\bar{X}=2.91)$ mezunu olan ebeveynlerin yaşam doyum düzeylerinin lisansüstü eğitim düzeyine $(\bar{X}=3.36)$ sahip ebeveynlerden anlamlı düzeyde düşük olduğunu göstermiş̧tir. Diğer eğitim düzeyleri arasında anlamlı bir farklılık gözlenmemiştir. Yetersizlik türü değişkenine göre ebeveynlerin yaşam doyum düzeylerinin $\mathrm{t}$ testi sonuçları Tablo 6 'da verilmiştir.

\section{Tablo 6}

Yetersizlik Türü Değişkenine Göre Ebeveynlerin Yaşam Doyum Düzeylerinin t Testi Sonuçları

\begin{tabular}{lcccccc}
\hline & Yetersizlik türü̈ $^{\mathrm{a}}$ & $n$ & $\bar{X}$ & $S S$ & $t$ & $p$ \\
\hline \multirow{2}{*}{ Yaşam doyumu } & ZY & 139 & 3.15 & .85 & \multirow{2}{*}{1.55} & \multirow{2}{*}{000} \\
& OSB & 170 & 2.98 & 1.08 & & \\
\hline
\end{tabular}

${ }^{\mathrm{a} Z Y}=$ zihin yetersizliği; $\mathrm{OSB}=$ otizm spektrum bozukluğu.

Tablo 6'da görüldüğü gibi ebeveynlerin yaşam doyum düzeyleri çocuklarının yetersizlik türü değişkeni açısından anlamlı bir fark göstermiştir $(t(308)=1.55 ; p<.05)$. Ölçek genel puanına göre, $\mathrm{ZY}$ olan çocukların ebeveynlerinin yaşam doyum düzeyi puan ortalamalarının OSB olan çocukların ebeveynlerinden anlamlı düzeyde yüksek olduğu bulgusuna ulaşılmıştır. Cinsiyet değişkenine göre ebeveynlerin yılmazlık düzeylerinin bağımsız gruplar $\mathrm{t}$ testi sonuçları Tablo 7'de verilmiş̧tir. 
Tablo 7

Cinsiyet Değişkenine Göre Ebeveynlerin Yılmazlık Düzeylerinin Bă̆ımsız Gruplar t Testi Sonuçları

\begin{tabular}{|c|c|c|c|c|c|c|}
\hline & Cinsiyet & $n$ & $\bar{X}$ & $S S$ & $t$ & $p$ \\
\hline \multirow{2}{*}{ Aile yılmazlığ 1 (Genel) } & Anne & 122 & 3.96 & .64 & \multirow{2}{*}{3.77} & \multirow{2}{*}{.000} \\
\hline & Baba & 187 & 3.66 & .73 & & \\
\hline \multirow{2}{*}{ Mücadelecilik } & Anne & 122 & 3.80 & .64 & \multirow{2}{*}{4.99} & \multirow{2}{*}{.000} \\
\hline & Baba & 187 & 3.38 & .80 & & \\
\hline \multirow{2}{*}{ Öz-yetkinlik } & Anne & 122 & 3.93 & .69 & \multirow{2}{*}{1.55} & \multirow{2}{*}{.126} \\
\hline & Baba & 187 & 3.71 & .87 & & \\
\hline \multirow{2}{*}{ Yaşama bağlılık } & Anne & 122 & 4.19 & .71 & \multirow{2}{*}{3.03} & \multirow{2}{*}{.003} \\
\hline & Baba & 187 & 4.06 & .70 & & \\
\hline \multirow{2}{*}{ Kendini kontrol } & Anne & 122 & 4.05 & .77 & \multirow{2}{*}{2.43} & \multirow{2}{*}{.021} \\
\hline & Baba & 187 & 3.76 & .86 & & \\
\hline
\end{tabular}

Tablo 7'de görüldüğü gibi anne ve babaların aile yılmazlık düzeylerinin bağımsız gruplar için yapılan t test analizleri annelerin yılmazlık düzeylerinin babaların yılmazlık düzeylerinden anlamlı derecede yüksek olduğunu göstermiştir $(t(308)=3.77, p<.05)$. Aile yılmazlık düzeyinin, Mücadelecilik $(t(308)=4.99, p<.05)$, Yaşama Bağlılık $(t(308)=1.55, p<.05)$ ve Kendini Kontrol $(t(308)=3.03, p<.05)$ alt boyutlarında da annelerin puanlarının anlamlı derecede babaların puanlarından yüksek olduğu görülmüştür. Öz-yetkinlik $(t(308)=2.43, p>$ .05) alt boyutunda ise anne ve babaların puanları arasında anlamlı bir farklılık gözlenmemiştir. Yaş değişkeni açısından ebeveynlerin yılmazlık düzeylerinin ANOVA sonuçları Tablo 8'de verilmiştir.

Tablo 8

Yaş Değişkeni Açısından Ebeveynlerin Yılmazlık Düzeylerinin ANOVA Sonuçları

\begin{tabular}{|c|c|c|c|c|c|c|}
\hline & Yaş & $n$ & $\bar{X}$ & $S S$ & $F$ & $p$ \\
\hline \multirow{4}{*}{ Aile y1lmazlığ (Genel) } & 30 yaş altı & 42 & 3.98 & .58 & \multirow{4}{*}{1.73} & \multirow{4}{*}{.161} \\
\hline & $31-40$ yas aras & 69 & 3.81 & .62 & & \\
\hline & $41-50$ yaş arası & 107 & 3.75 & .74 & & \\
\hline & 51 ve üstü & 91 & 3.69 & .78 & & \\
\hline \multirow{4}{*}{ Mücadelecilik } & 30 yas alt1 & 42 & 3.72 & .69 & \multirow{4}{*}{.10} & \multirow{4}{*}{.394} \\
\hline & $31-40$ yaş aras 1 & 69 & 3.57 & .62 & & \\
\hline & $41-50$ yaş aras & 107 & 3.50 & .83 & & \\
\hline & 51 ve üstü & 91 & 3.51 & .82 & & \\
\hline \multirow{4}{*}{ Öz-yetkinlik } & 30 yaş altı & 42 & 4.33 & .56 & \multirow{4}{*}{2.68} & \multirow{4}{*}{.047} \\
\hline & $31-40$ yaş arası & 69 & 4.16 & .60 & & \\
\hline & $41-50$ yaş arası & 107 & 4.11 & .72 & & \\
\hline & 51 ve üstü & 91 & 3.97 & .80 & & \\
\hline \multirow{4}{*}{ Yaşama bağl1lık } & 30 yaş alt1 & 42 & 4.11 & .61 & \multirow{4}{*}{1.93} & \multirow{4}{*}{.125} \\
\hline & $31-40$ yaş aras 1 & 69 & 3.94 & .86 & & \\
\hline & $41-50$ yaş aras 1 & 107 & 3.84 & .83 & & \\
\hline & 51 ve üstü & 91 & 3.76 & .89 & & \\
\hline \multirow{4}{*}{ Kendini kontrol } & 30 yaş alt1 & 42 & 4.04 & .65 & \multirow{4}{*}{2.06} & \multirow{4}{*}{.106} \\
\hline & $31-40$ yas aras 1 & 69 & 3.73 & .86 & & \\
\hline & $41-50$ yaş arası & 107 & 3.84 & .73 & & \\
\hline & 51 ve üstü & 91 & 3.69 & .91 & & \\
\hline
\end{tabular}

Tablo 8'de görüldüğü gibi ebeveynlerin genel yılmazlık düzeyleri yaş değişkeni açısından incelendiğinde yaşlar arasında anlamlı bir fark gözlenmemiştir $(F(3,305)=1.73, p>.05)$. Mücadelecilik $(F(3,305)=.10, p>$ $.05)$, Yaşama Bağlılık $(F(3,305)=1.93, p>.05)$ ve Kendini Kontrol $(F(3,305)=2.06, p>.05)$ alt boyutlarında ebeveynlerin yaşları arasında anlamlı bir farklılık gözlenmemiştir. Ölçekten elde edilen veriler, sadece Özyetkinlik alt boyutunda yaşlar arasında anlamlı bir farklılık olduğunu göstermiştir $(F(3,305)=2.68, p<.05)$. Özyetkinlik alt boyutundaki bu anlamlı farklılığın hangi yaş grupları arasında olduğunu belirlemek için yapılan Tukey HSD Testi sonuçları anlamlı farklılı̆̆ın 30 yaş altı $(\bar{X}=4.33)$ ve 51 ve üstü yaşlarında $(\bar{X}=3.97)$ olan ebeveyn grupları arasında olduğunu göstermiştir. Farklı bir ifade ile Öz-yetkinlik alt boyutunda yaşı genç olanlardan yana anlamlı bir farklılık gözlenmiştir. Diğer yaş grupları arasında da öz-yetkinlik alt boyutu açısından anlamlı bir 

DOYUMU VE AİLE YILMAZLIK DÜZEYLERINIIN İNCELENMESİ

farklılık görülmemektedir. Gelir düzeyi değişkeni açısından ebeveynlerin yılmazlık düzeylerinin ANOVA sonuçları Tablo 9'da verilmiştir.

\section{Tablo 9}

Gelir Düzeyi Değişkeni Açısından Ebeveynlerin Yllmazlık Düzeylerinin ANOVA Sonuçları

\begin{tabular}{|c|c|c|c|c|c|c|}
\hline & Gelir & $n$ & $\bar{X}$ & $S S$ & $F$ & $p$ \\
\hline \multirow{5}{*}{ Aile y1lmazlığ } & 2500 ve alt1 & 88 & 3.75 & .75 & \multirow{5}{*}{3.65} & \multirow{5}{*}{.076} \\
\hline & $2501-3500$ aras 1 & 105 & 3.83 & .74 & & \\
\hline & $3501-4500$ aras 1 & 61 & 3.90 & .52 & & \\
\hline & $4501-5500$ aras 1 & 30 & 3.82 & .78 & & \\
\hline & 5501 ve üstü & 25 & 4.00 & .62 & & \\
\hline \multirow{5}{*}{ Mücadelecilik } & 2500 ve alt 1 & 88 & 3.33 & .82 & \multirow{5}{*}{2.89} & \multirow{5}{*}{.083} \\
\hline & $2501-3500$ aras 1 & 105 & 3.59 & .78 & & \\
\hline & $3501-4500$ aras 1 & 61 & 3.61 & .66 & & \\
\hline & $4501-5500$ aras1 & 30 & 3.72 & .79 & & \\
\hline & 5501 ve üstü & 25 & 3.76 & .58 & & \\
\hline \multirow{5}{*}{ Öz yetkinlik } & 2500 ve alt 1 & 88 & 3.19 & .70 & \multirow{5}{*}{3.83} & \multirow{5}{*}{.005} \\
\hline & $2501-3500$ aras 1 & 105 & 4.16 & .76 & & \\
\hline & $3501-4500$ aras 1 & 61 & 4.30 & .47 & & \\
\hline & $4501-5500$ aras1 & 30 & 4.05 & .82 & & \\
\hline & 5501 ve üstü & 25 & 4.27 & .71 & & \\
\hline \multirow{5}{*}{ Yaşama bağl1lık } & 2500 ve alt 1 & 88 & 3.84 & .85 & \multirow{5}{*}{3.033} & \multirow{5}{*}{.098} \\
\hline & $2501-3500$ aras 1 & 105 & 3.90 & .88 & & \\
\hline & $3501-4500$ aras 1 & 61 & 4.05 & .64 & & \\
\hline & $4501-5500$ aras1 & 30 & 3.91 & .88 & & \\
\hline & 5501 ve üstü & 25 & 4.12 & .79 & & \\
\hline \multirow{5}{*}{ Kendini kontrol } & 2500 ve alt 1 & 88 & 3.90 & .81 & \multirow{5}{*}{9.58} & \multirow{5}{*}{.085} \\
\hline & $2501-3500$ aras 1 & 105 & 3.97 & .86 & & \\
\hline & $3501-4500$ aras 1 & 61 & 3.95 & .52 & & \\
\hline & $4501-5500$ aras 1 & 30 & 3.79 & .81 & & \\
\hline & 5501 ve üstü & 25 & 3.75 & .72 & & \\
\hline
\end{tabular}

Tablo 9'da görüldüğü gibi ebeveynlerin genel aile yılmazlık düzeylerinin gelir düzeyi değişkeni açısından analiz edildiğinde gelir düzeyleri arasında genel ölçek bulgularında anlamlı bir farklılık gözlenmemiştir $(F(4,304)$ $=3.65, p>.05)$. Alt ölçekler temelinde el alındığında, ebeveynlerin, gelir düzeyi değişkeni açısından Yaşama $\operatorname{Bağl} 1$ lik $(F(4,304)=3.03, p>05)$ ve Kendini $\operatorname{Kontrol}(F(4,304)=9.58, p>.05)$ alt boyutlarında yapilan analizler sonucunda anlamlı bir farklılık gözlenmemiştir. Bununla birlikte Mücadelecilik $(F(4,304)=2.87, p<.05)$ ve Özyetkinlik $(F(4,304)=3.85, p<.05)$ alt boyutlarında gelir düzeyleri arasında anlamı bir farklılık gözlenmiştir. Tukey HSD testi sonucuna göre 2500 TL ve altında geliri olan ebeveynlerin öz-yetkinlik düzeyleri 3501-4500 TL geliri olan ebeveynlere kıyasla anlamlı düzeyde düşüktür. Eğitim düzeyi değişkeni açısından ebeveynlerin yılmazlık düzeylerinin ANOVA sonuçları Tablo 10’da verilmiştir. 
Tablo 10

Ĕ̆itim Düzeyi Değişkeni Açısından Ebeveynlerin Yılmazlık Düzeylerinin ANOVA Sonuçları

\begin{tabular}{|c|c|c|c|c|c|c|}
\hline & Eğitim düzeyi & $n$ & $\bar{X}$ & $S S$ & $F$ & $p$ \\
\hline \multirow{4}{*}{ Aile yılmazlığg (Genel) } & İlköğretim & 86 & 3.66 & .76 & \multirow{4}{*}{2.02} & \multirow{4}{*}{.111} \\
\hline & Ortaöğretim & 79 & 3.82 & .72 & & \\
\hline & Lisans & 80 & 3.91 & .69 & & \\
\hline & Lisansüstü & 64 & 3.70 & .63 & & \\
\hline \multirow{4}{*}{ Mücadelecilik } & İlköğretim & 86 & 3.41 & .76 & \multirow{4}{*}{3.36} & \multirow{4}{*}{.019} \\
\hline & Ortaöğretim & 79 & 3.63 & .80 & & \\
\hline & Lisans & 80 & 3.72 & .75 & & \\
\hline & Lisansüstü & 64 & 3.41 & .72 & & \\
\hline \multirow{4}{*}{ Öz yetkinlik } & İlköğretim & 86 & 4.02 & .83 & \multirow{4}{*}{.99} & \multirow{4}{*}{.399} \\
\hline & Ortaöğretim & 79 & 4.15 & .67 & & \\
\hline & Lisans & 80 & 4.20 & .65 & & \\
\hline & Lisansüstü & 64 & 4.07 & .63 & & \\
\hline \multirow{4}{*}{ Yaşam bağlılık } & İlköğretim & 86 & 3.78 & .91 & \multirow{4}{*}{.65} & \multirow{4}{*}{.586} \\
\hline & Ortaöğretim & 79 & 3.87 & .87 & & \\
\hline & Lisans & 80 & 3.95 & .79 & & \\
\hline & Lisansüstü & 64 & 3.91 & .74 & & \\
\hline \multirow{4}{*}{ Kendini kontrol } & İlköğretim & 86 & 3.70 & .80 & \multirow{4}{*}{2.05} & \multirow{4}{*}{.107} \\
\hline & Ortaöğretim & 79 & 3.79 & .79 & & \\
\hline & Lisans & 80 & 3.98 & .93 & & \\
\hline & Lisansüstü & 64 & 3.71 & .66 & & \\
\hline
\end{tabular}

Tablo 10’da görüldüğü gibi ebeveynlerin aile yılmazlık düzeyleri eğitim düzeyi değişkeni açısından değerlendirildiğinde genel ölçek bulguları ebeveynlerin eğitim düzeyleri arasında anlamlı farklılık göstermemiştir $(F(3,305)=2.02, p>.05)$. Ölçekten elde edilen veriler ebeveynlerin eğitim düzeyleri değişkenine göre analiz edildiğinde Mücadelecilik alt boyutunda anlamlı farklılık gözlenmiştir $(F(3,305)=3.36, p<.05)$. Öz-yetkinlik $(F(3,305)=0.99, p>.05)$, Yaşama Bağlılık $(F(3,305)=0.65, p>.05)$ ve Kendini Kontrol $(F(3,305)=2.05, p>$ $.05)$ alt boyutlarında ise anlamlı bir farklılık gözlenmemiştir. Mücadelecilik alt boyutunda hangi eğitim düzeyine sahip ebeveynler arasında anlamlı farkın olduğunu belirlemek için yapılan Tukey HSD testi sonucunda, lisans $(\bar{X}$ = 3.72) düzeyinde eğitimi olan ebeveynlerin Mücadelecilik puanlarının ilköğretim $(\bar{X}=3.41)$ düzeyinde eğitime sahip ebeveynlerden anlamlı düzeyde yüksek olduğu bulunmuştur. Diğer eğitim düzeyleri arasında anlamlı bir fark gözlenmemiştir. Çocuklarının yetersizlik türü değişkeni açısından ebeveynlerin yılmazlık düzeylerinin $t$ testi sonuçları Tablo 11'de verilmiştir.

\section{Tablo 11}

Çocuklarının Yetersizlik Türü Değişkeni Açısından Ebeveynlerin Yılmazlık Düzeylerinin t Testi Sonuçları

\begin{tabular}{lcccccc}
\hline & Yetersizlik $^{\mathrm{a}}$ & $n$ & $\bar{X}$ & $S S$ & $t$ & $p$ \\
\hline \multirow{2}{*}{ Aile yılmazlığı (Genel) } & ZY & 139 & 3.83 & .68 & 3.44 & .033 \\
& OSB & 170 & 3.68 & .75 & & \\
Mücadelecilik & ZY & 139 & 3.59 & .76 & 3.46 & .033 \\
& OSB & 170 & 3.45 & .80 & & \\
Öz yetkinlik & ZY & 139 & 4.14 & .67 & 3.04 & .049 \\
& OSB & 170 & 4.03 & .76 & & \\
Yaşama bağlılık & ZY & 139 & 3.94 & .81 & 3.64 & .027 \\
\multirow{2}{*}{ Kendini kontrol } & OSB & 170 & 3.76 & .88 & & \\
& ZY & 139 & 3.91 & .69 & 2.02 & .135 \\
\hline
\end{tabular}

${ }^{\mathrm{a} Z Y}=$ zihin yetersizliği; OSB = otizm spektrum bozukluğu.

Tablo 11'de görüldüğü gibi çocuklarının yetersizlik türü değişkeni açısından ebeveynlerin aile yılmazlık düzeylerinin genel ölçekte bağımsız gruplar için yapılan t test bulgularına göre ZY olan çocuğa sahip ebeveynlerin aile yılmazlık düzeylerinin OSB olan çocukların ebeveynlerinden anlamlı düzeyde yüksek olduğu görülmüştür $(t(308)=3.44, p<.05)$. Ölçekten elde edilen verilerde Mücadelecilik $(t(308)=3.46, p<.05)$, Öz-yetkinlik $(t(308)=$ 
$3.04, p<.05)$ ve Yaşama Bağl1lık $(t(308)=3.64, p<.05)$ alt boyutlarında da ZY olan çocuğa sahip ebeveynlerin puanlarının anlamlı olarak yüksek olduğu gözlenmiştir. Buna rağmen, Kendini Kontrol $(t(308)=2.02, p>.05)$ alt boyutunda yetersizlik türüne göre ebeveynler arasında anlamlı bir farklılık gözlenmemiştir. Tablo 12'de Ebeveynlerin Yaşam Doyumu ve Aile Yılmazlık düzeyleri arasındaki ilişkin bulgulara yer verilmiştir. Ebeveynlerin yaşam doyumu ve aile yılmazlık düzeyleri arasındaki ilişkiler Tablo 12'de verilmiştir.

\section{Tablo 12}

Ebeveynlerin Yaşam Doyumu ve Aile Yllmazlık Düzeyleri Arasindaki İlişkilere Yönelik Pearson Korelasyon Katsayıları $(N=309)$

\begin{tabular}{|c|c|c|c|c|c|c|}
\hline & $\begin{array}{c}\text { Yaşam } \\
\text { Doyumu }\end{array}$ & Aile Y1lmazlığ & Mücadelecilik & Öz Yetkinlik & $\begin{array}{l}\text { Yaşama } \\
\text { Bağlılık }\end{array}$ & $\begin{array}{l}\text { Kendini } \\
\text { Kontrol } \\
\end{array}$ \\
\hline Yaşam Doyumu & 1 & & & & & \\
\hline Aile Y1lmazlığ & $.626^{*}$ & & & & & \\
\hline Mücadelecilik & $.580^{*}$ & $.957^{*}$ & & & & \\
\hline Öz-yetkinlik & $.524^{*}$ & $.904^{*}$ & $.779^{*}$ & & & \\
\hline Yaşama Bağlılık & $.633^{*}$ & $.932^{*}$ & $.847^{*}$ & $.813^{*}$ & & \\
\hline Kendini Kontrol & $.536^{*}$ & $.732^{*}$ & $.605^{*}$ & $.727^{*}$ & $.634^{*}$ & \\
\hline
\end{tabular}

Tablo 12'de görüldüğü gibi yaşam doyumu ile $(r=.626, p<.01)$ aile yılmazlığı arasında pozitif bir ilişki bulunmaktadır. Bunun yanında yaşam doyumu ile aile yılmazlığı ölçeği alt boyutlarından Mücadelecilik $(r=.580$, $p<.01)$, Öz-yetkinlik $(r=.524, p<.01)$, Yaşama Bağll1ık $(r=.633, p<.01)$ ve Kendini Kontrol $(r=.536, p<$ $.01)$ alt boyutlarında da pozitif yönde olumlu ilişki olduğu gözlenmektedir.

\section{Tartışma}

$\mathrm{Bu}$ araștırma, OSB ve ZY olan çocukların ebeveynlerinin çocuklarının yetersizliği ilişkili deneyimlerini daha iyi anlamak amacıyla cinsiyet, çocuklarının yetersizlik türü, yaş, gelir düzeyi, ebeveynlerin eğitim düzeyi değişkenleri ile yaşam doyumu ve aile yılmazlık düzeyleri arasındaki ilişkiyi incelemeyi amaçlamıştır.

Araştırmada, annelerin yaşam doyum düzeylerinin babaların yaşam doyumu düzeylerinden anlamlı derecede yüksek olduğu gözlenmiştir. Yaşam doyumuyla ilgili alan yazın incelendiğinde bu araştırmanın bulgularından farklı olarak babaların yaşam doyum düzeylerinin daha yüksek olduğu sonucuna ulaşan araştırmalarla karşılaşılmaktadır (Akandere vd., 2009; Sarıkaya, 2011). Ayrıca, ebeveynlerin cinsiyet değişkeni açısında yaşam doyum düzeylerinde anlamlı bir farklılık olmadığını ileri süren araştırmalar da bulunmaktadır (Deniz vd., 2009; Diener vd., 1995; Hisoğlu, 2018; İnce \& Tüfekci, 2015; Kaner, 2004; Kantar, 2014; Karande \& Kulkarni, 2009; Nergiz, 2013). Buna karşın, özel gereksinimli çocuğun bakım yükünün daha çok annelerin üzerinde olması nedeniyle stres düzeylerinin daha yüksek ve depresif bulgularının daha fazla olduğunu belirten çalışmalar da bulunmaktadır (Cummings vd., 1996). Bu araştırmada annelerin yaşam doyumlarının yüksek düzeyde olması annelik içgüdüsünden kaynaklanıyor olabilir. Anne hamile kaldığı andan itibaren çocuğuyla bir bağ geliştirmeyesi hamileliğinde tüm sıkıntılarına katlanmasına ve yorucu da olsa, memnuniyetle çocuğuyla ilgilenmesine annelik içgüdüsü denilmektedir (Sari, 2014). Alanyazında "Aile yapısında anne-çocuk arasındaki ilişkinin, eşler arasındaki ilişkiden daha güçlü” olduğunu bildiren araştırmalar bulunmaktadır (Şanlı \& Öztürk, 2015). Bu tespitten hareketle bu araştırma bağlamında çocuklarıyla kurdukları yakın bağın annelerin çocuklarını daha fazla sahiplenmelerine ve yaşam doyum düzeylerinin yüksek olmasına neden olduğu söylenebilir. Ayrıca çocuğun bakımını sağlamak toplumumuzda kadına yüklenen en temel sorumluluklardan biridir (Tuğrul, 2019). Kadınlara atfedilen bu bakım yükü çocukluktan itibaren öğretilmektedir. Genellikle toplumumuzda kız çocuğuna evde bakım işleri, erkek çocuğa ise çalışıp eve maddi gelir getirme görevi öğretilmektedir (Aykara, 2015). Bu gibi kültürel öğretiler, annelerin çocuğun bakımını görev olarak görmelerini ve bu durumu kabullenmelerini sağlayarak yaşam doyum düzeylerinin olumsuz etkilenmemesini sağlamış olabilir.

Ebeveynlerin yaşı da stresli durumlara verilen tepkileri etkileyen değişkenler arasındadır. Bu araştırmada, ebeveynlerin yaşam doyum düzeyleri yaş değişkeni açısından incelendiğinde, genç yaştaki ebeveynlerin daha yüksek yaşam doyumu düzeyine sahip oldukları görülmüş̧ür. İlgili araştırmalar genellikle yaş arttıkça yaşam doyumunun da arttığını göstermektedir (Akandere vd., 2009; Boztaş \& Tutkun, 2017; Çattık \& Aksoy, 2018; Gülaldı, 2010; Huang vd., 2014; Kantar, 2014; Lee vd., 2009; Sarıkaya, 2011; Satılmış, 2020). Bu araştırmada, genç yaş gruplarındaki ebeveynlerin yaşam doyumu düzeylerinin daha yüksek olması genç ebeveynlerin 
çocuklarının yaşlarının küçük olması nedeniyle okul veya diğer sosyal ortamlarla ilgili olumsuzluklarla henüz karşılaşmamalarına ve dolayısıyla yaşama daha olumlu ve umutlu bakmalarına bağlanabilir. Alan yazına baktığımızda, Seltzer ve arkadaşları (1993) Down Sendromlu çocuğu olan genç annelerin daha az stresli ve aile ilişkilerinin daha olumlu olduğunu ve çatışmadan daha çok çekinen bireyler olduğunu bulmuşlardır.

Araştırmada gelir düzeyi yüksek olan ebeveynlerin yaşam doyumu düzeyleri diğer gelir düzeyine sahip olanlara göre daha yüksek bulunmuştur. Alanyazında bu araştırma bulgularını destekleyen ve gelir düzeyinin yaşam doyumunu arttırdı̆̆ını bildiren çalışmalara rastlanmaktadır (Akandere vd., 2009; Diener, 2009; İnce \& Tüfekci, 2015; Lu vd., 2018; Sarıkaya, 2011; Yavuz, 2016). Buna karşın Çattık ve Aksoy (2018) ve Satılmış (2020) yaptıkları araştırmada gelir düzeyi ile yaşam doyumu arasında anlamlı bir ilişki gözlememişlerdir. Bu araştırma sonucuna göre de gelir düzeyi arttıkça yaşam doyumu düzeyinin yükseldiği görülmektedir. Gelir düzeyi yaşam doyumunun yordayıcılarındandır (Akandere vd., 2009; Diener, 2009). Bireyin gelir düzeyi yüksek olduğunda hem yetersizliği olan çocuğu hem de kendisi için iyi eğitim ve bakım imkânlarını sağlaması daha kolay olmaktadır (Turnbull vd., 2006). Dolayısıyla, ebeveynlerin ekonomik açıdan daha az stres ve kaygı yaşamaları yaşam doyumlarının artmasını beraberinde getirmektedir.

Araştırmanın bir diğer bulgusuna göre ebeveynlerin eğitim düzeyleri artıkça yaşam doyum düzeyleri de artmaktadır. Bu araştırmanın bulgularıyla paralellik gösteren araştırmalarla (Akandere vd., 2009; Coşkun, 2018; Diener, 2009; Gülaldı, 2010; Sarıkaya, 2011) karşılaşıldığı gibi yaşam doyumunun eğitim seviyesine göre farklılaşmadığını tespit eden araştırmalar da bulunmaktadır (Çattık \& Aksoy, 2018; Kantar, 2014; Karande \& Kulkarni, 2009; Lee vd., 2009; Pozo vd., 2014; Satılmış, 2020; Steger vd., 2006). Eğitim düzeyi yüksek ebeveynler yetersizliği olan çocuklarının sağlık problemleri ve uygun eğitim ortamları vb. sorunları ile ilgili bilgiye ve kaynaklara daha kolay erişebilecek (Sarıkaya, 2011) ve daha az stres yaşamalarının bu bulguyu açıklayabileceği düşünülmektedir (Smith vd., 2001).

Araştırmada ayrıca ZY olan çocukların ebeveynlerinin yaşam doyum düzeylerinin OSB olan çocukların ebeveynlerine göre daha yüksek olduğu tespit edilmiştir. Alan yazında farklı yetersizlik gruplarıyla yapılan araştırmalar incelediğinde ebeveynlerin yaşam doyumlarının çocuğun yetersizlik türüne göre farklılaştı̆̆ görülmektedir. Örneğin, bir araştırmada ZY olan çocukların babalarının yaşam doyum düzeyleri FY olan babalara kıyasla daha yüksek düzeydedir (Akandere vd., 2009). Bir diğer araştırmaya göre görme yetersizliği, işitme yetersizliği ve diğer engel türünden olan ebeveynlerin yaşam doyum düzeyleri Down Sendromu/ZY olan çocukların ebeveynlerinin yaşam doyum düzeyin daha yüksektir (Deniz vd., 2009). Yavuz'un (2016) araştırmasına göre ise normal gelişim gösteren bireylerin ebeveynlerinin yaşam doyumu ZY olan çocukların ebeveynlerinden daha yüksektir. $\mathrm{Bu}$ araştırmada OSB olan çocukların ebeveynlerinin yaşam doyum düzeyinin düşük olmasının OSB'nin özelliklerinden kaynaklı olabileceği düşünülmektedir. OSB olan bireyler daha fazla davranış problemi sergilemekte (Hartley vd., 2016) ve daha fazla bakım istemektedirler (Aydın \& Egin, 2018). Bunun yanı sıra OSB olan çocukların göz teması kurmaması, dokunulmaktan hoşlanmaması gibi özellikleri ebeveynlerin çocuklarının kendilerine karşı olan sevgilerini hissedememelerine sebep olmaktadır (Kaya, 2015). Bu özelliklerin OSB olan çocuğa sahip ebeveynlerin yaşam doyum düzeylerini olumsuz etkilediği düşünülmektedir. Söz konusu nedenlerin etkisiyle bu bireylerin ebeveynlerinde diğer ebeveynlere oranla daha fazla psikolojik problem gözlenmektedir.

Araştırmada, yaşam doyumu düzeylerinin yanı sıra ebeveynlerin yılmazlık düzeyleri de incelenmiştir. Annelerin aile yılmazlık düzeylerinin genel ölçek bulgularına göre ve Mücadelecilik, Yaşama bağlllık ve Kendini Kontrol alt boyutlarında babalardan daha yüksek olduğu bulunmuştur. Alan yazına bakıldığında bu araştırma bulgularıyla paralel çeşitli araştırma bulguları bulunmaktadır. Aysever ve Demirok (2019) yaptıkları araştırmada Aile Yılmazlık Ölçeği'nin Mücadelecilik alt boyutunda, Kumbasar (2016) ölçek Öz-yetkinlik alt boyutunda annelerin lehine anlamlı farklılıklar bulmuşlardır. Buna karşın Campbell-Sills ve diğerleri (2009) ile Lee ve arkadaşları (2009) babaların daha yılmaz olduklarını bildirmektedirler. Çoklu yetersizliği olan bireylerin babalarının annelere göre Mücadelecilik alt boyutunda yılmazlık düzeylerinin daha yüksek olduğuna yönelik bulgular da mevcuttur (Kadı, 2016). Ayrıca, aile yılmazlık düzeyinin anne ya da baba olma açısından anlamlı bir fark göstermediğini bildiren araştırmalar da bulunmaktadır (Kaner vd., 2011; Plumb, 2011; Turan, 2017). Bu araştırmaya katılan annelerin daha yılmaz olmalarının nedeni, yaşam doyumlarının yüksek olmasından (Hastings vd., 2002) ve daha olumlu bir bakış açısına sahip olmalarından bağlanabilir. Annelerin daha yılmaz olmalarının bir diğer nedeni Aslan'ın (2010) da vurguladığı gibi sosyal desteğe daha fazla başvurmaları olabilir. Sahip oldukları sosyal desteklerin artması annelerin stresle daha etkili bir şekilde başa çıkmalarına ve daha yılmaz olmalarına katkıda bulanabilir. Bu durumu Aslan'ın (2010) “Annelerin çocuklara devamlı bakım veren konumunda olmaları ve içinde bulundukları durumu aile eve özel kişilerle daha fazla paylaştıklarından sosyal destek ağlarının gelişmiş olabileceği düşünülmektedir” şeklinde açıklamaktadır. 
Ebeveynlerin yılmazlık düzeyleri yaş değişkeni açısından incelendiğinde Öz-yetkinlik alt boyutunda genç ebeveynlerin yılmazlık düzeylerinin daha yüksek olduğu bulunmuştur. Aysever ve Demirok (2019) yaptıkları araştırmada ölçeğin Kendini Kontrol alt boyutunda Kaner ve diğerleri (2011) Öz-yetkinlik ve Yaşama Bağlllık alt boyutlarında yaşı genç ebeveynlerin daha yılmaz olduğu sonucuna ulaşmıştır. Benzer şekilde Lee ve arkadaşları (2009) da genç yaştaki ebeveynlerin kendilerini daha yılmaz olarak algıladıklarını belirtmektedir. Buna karşın alan yazında yaşla birlikte yılmazlık düzeyinin arttığını bildiren çalışmalar da yer almaktadır (Campbell-Sills vd., 2009; Lloyd \& Hastings, 2009). Bunların yanında yaş değişkeninin aile yılmazlık düzeyi ile anlamlı bir ilişsisinin olmadığını bildiren araştırmalar da bulunmaktadır (Kadı, 2016; Turan, 2017). Bu araşıırma sonuçlarına göre Özyetkinlik alt boyutuna göre genç ebeveynlerin daha yılmaz olarak gözlenmesinin nedeni genç ebeveynlerin çocuklarının küçük olması nedeniyle umutlarının daha fazla olması, yetersizliğin olumsuz etkilerinden daha az etkilenmiş olmaları olabilir (Kaner vd., 2011).

Gelir düzeyi değişkeni açısından aile yılmazlık düzeyleri genel ölçek bulguları ve ölçek alt boyutlarından Mücadelecilik, Yaşama Bağlllık ve Kendini Kontrol alt boyutları incelendiğinde gelir düzeyi yüksek olan ebeveynlerin yılmazlık düzeylerinin yüksek olduğu gözlenmiştir. Alan yazın incelendiğinde bu araştırma bulgularıly benzer sonuçlara (Bhana \& Bachoo, 2011; Campbell-Sills vd., 2009; Greeff \& Walt, 2010; Walsh, 2003; Taşdemir, 2013) rastlanmasına karşın, gelir düzeyi ile aile yılmazlık düzeyi arasında bir ilişki olmadığını belirten araştırmalarla da karşılaşılmaktadır (Kadı, 2016; Kumbasar, 2016; Turan, 2017). Bu araştırmanın bulgularından yola çıkılarak ailenin sahip olduğu maddi olanakların ebeveynlerin yılmazlığını etkilediği söylenebilir. Çünkü maddi imkânları fazla olan ebeveynler gerekli bilgi eğitim, sağlık gibi hizmetlere daha kolay ulaşacaklardır. Bu da ebeveynlerin çocuğun durumundan kaynaklı sorunlara çözüm bulmalarını kolaylaştıracak, strese ve depresyona karşı koruyacak ve daha yılmaz olmalarını sağlayacaktır (Mcconnell vd., 2014; Upadhyaya \& Havalappanavar, 2008).

$\mathrm{Bu}$ araştırmanın bir diğer bulgusu yetersizliği olan çocuğa sahip ebeveynlerin eğitim düzeyi ile aile yılmazlığı arasında anlamlı bir fark olmadığı şeklindedir. Ancak, Mücadelecilik alt boyutunda lisans mezunu ebeveynlerin ilköğretim mezunu ebeveynlerden daha yüksek puan aldıkları görülmüsstür. Alan yazında bu araştırma bulgularıyla benzer araştırmalarla (Aysever \& Demirok, 2019; Campbell-Sills vd., 2009; Turan, 2017) karşılaşıldığı gibi eğitim düzeyinin ebeveynlerin yılmazlık düzeyini etkilemediğini bildiren araştırmalarda bulunmaktadır (Kadı, 2016; Kaner vd., 2011; Kumbasar, 2016; Plumb, 2011; Ryan \& Caltabiano, 2009; Taşdemir, 2013). Ebeveynlerin eğitim düzeyinin düşük olması aynı zamanda gelir düzeyinin de düşük olmasının göstergesi olabilmektedir (Moh \& Magiati, 2012). Bu durum da ebeveynlerin çocuklarının eğitim, sağlık ve diğer gereksinimlerini karşılamada yetersiz kalmasına (Turnbull vd., 2006) ve strese ve depresyona daha açık olmalarına yol açacaktır. Buna karşın eğitim düzeyi yüksek aileler yetersizliği olan çocuklarının gereksinimlerini önceden fark edip bu ihtiyaçlarını çocukları için sağlayabileceklerdir. Böylelikle de stres ve depresyon Yaşama olasılıkları azalacaktır.

Yetersizlik türü değişkenine göre ebeveynlerin yllmazlık düzeyleri genel ölçek puanında ve ölçek alt boyutlarından Mücadelecilik, Öz-yetkinlik ve Yaşama Bağlllık alt boyutlarında OSB olan çocukların ebeveynleriyle karşılaştırıldıklarında ZY olan çocukların ebeveynlerinden yana anlamlı farklılık gözlenmiştir. Kaner (2004) yaptığı araştırmada ZY olan çocukların ebeveynlerinin, işitme yetersizliği çocukların ebeveynlerine oranla kendilerini daha çok yetersiz hissettikleri sonucuna ulaşmıştır. Kaner ve diğerleri (2011) normal gelişim gösteren çocuğa sahip ebeveynlerin kendilerini ZY olan çocuğun ebeveynlerine göre daha yılmaz algıladıklarını bildirmişlerdir. Uğuz ve diğerleri (2004) bedensel yetersizliği ve ZY olan çocuğu olan annelerin, yetersizliği olmayan çocukların annelerinden daha çok psikolojik sorunlar yaşadıklarını belirtmişlerdir. Buna karşın yetersizlik türünün ebeveynlerin psikolojisini etkilemediğini bildiren araştırmalar da bulunmaktadır. Çengelci (2009) OSB ve DS olan çocuğa sahip olan annelerin tükenmişlik, umutsuzluk ve kaygı puanları arasında fark bulamamıştır. Ha ve diğerleri (2008) ruhsal sağlık sorunları olan çocuklar ile gelişimsel yetersizliği olan çocukların ailelerinin stres düzeyleri arasında fark gözlememiştir. Kocakaya (2017) yaptığı araştırmada ağır yetersizliği olan bireylerle, ağır yetersizliği bulunmayan bireylerin aileleri arasında fark gözlememiştir. Palancı (2018) normal gelişim gösteren çocukların ebeveynlerinin yetersizliği olan çocukların ebeveynleriyle karşılaştırıldıklarında yılmazlık düzeylerinin yüksek olduğunu bulmuştur. Bu araştırma sonucuna göre $\mathrm{ZY}$ olan çocukların ebeveynlerinin yılmazlık düzeylerinin yüksek olması OSB'nin ağır yetersizlik gurubu içinde olmasından kaynaklanıyor olabilir. Tüm gelişim alanlarında yetersizlikleri olan OSB olan çocuklar davranış sorunlarını daha fazla sergilemekte (Hartley vd., 2016; Huang vd., 2014; Şafak, 2012) ve daha fazla bakım istemektedirler (Aydın \& Egin, 2018). Bu sorunlar da ailelerde daha fazla strese neden olarak yılmazlık düzeylerini etkilemiş olabilir. OSB ve Down Sendromu ve normal gelişim gösteren çocukların ebeveynleriyle yapılan çalışmada OSB olan çocukların ebeveynlerinin stres düzeylerinin daha yüksek olduğu sonucuna ulaşılmıştır (Dabrowska \& Pisula, 2010; Pottie \& Ingram, 2008). 
Yaşam doyumu ve aile yılmazlığı ve tüm alt boyutları arasında pozitif yönlü ilişki olduğu araştırmanın bir diğer bulgusu olmuştur. Alan yazına baktığımızda bu araştırma bulgularıyla benzerlik gösteren çeşitli araştırmalar bulunmaktadır (Akbar vd., 2014; Bingham, 2004; Demiray, 2019; Openshaw, 2011; Palanc1, 2018). Palanc1 (2018) yaptığı araştırmada OSB ve ZY olan çocukların ebeveynleri arasında aile yılmazlığı ile yaşam doyumu arasında pozitif yönlü korelasyon olduğunu bildirmiştir. Bingham (2004) yaptığ1 araştırmada çocuklukta kötü muamele görmüş bireylerde yılmazlık ve yaşam doyumları arasında pozitif yönlü korelasyon gözlemiştir. Openshaw (2011) yaptığı araştırmada yetersizliği olan bireylerin ebeveynlerinin aile yılmazlığı ile yaşam doyumu arasında güçlü korelasyon gözlemişlerdir. Akbar ve diğerleri (2014) yaptıkları araştırmada göçebe yaşayan bireylerin yılmazlık düzeyi ile yaşam doyumu arasında güçlü bir korelasyon olduğunu bildirmişlerdir. Palancı (2018) yetersizliği olan bireylerin ebeveynleriyle yaptığı araştırmada aile yılmazlığı ile yaşam doyumu arasında pozitif yönlü korelasyon gözlemiştir. Demiray (2019) yaptığı araştırmada özel gereksinimli çocuğa sahip ebeveynlerin aile yaşam kalitesi arasında pozitif yönlü ilişki gözlemiştir. Bu araştırmada yaşam doyumu ile aile yılmazlık ölçeğinin alt boyutlarından "Mücadelecilik", “Öz-yetkinlik" ve "Yaşama Bağl1lık” arasında tespit edilen zayıf düzeyde ve pozitif yönlü ilişki ailelerin mücadelecilik, öz-yetkinlik ve yaşama bağlılık düzeyleri arttıkça aile yaşam kalitelerinin de arttığı şeklinde yorumlanabilir.

$\mathrm{Bu}$ araştırma sonucuna göre yaşam doyumu yüksek olan bireylerin yılmazlık düzeylerinin de yüksek olduğu görülmektedir. Yaşam doyumu yüksek bireyler hayatın acı ve olumsuz yönlerini inkâr etmeden yaşama olumlu yönleriyle bakmakta (Avşaroğlu \& Okutan, 2018), daha iyimser olup daha az stres yaşamakta ve karşılaştıkları sorunları daha kolay aşabilmekte (Sirgy vd., 2006), yaptığı işlerden daha hoşnut ve daha mutlu olabilmektedirler (Telman \& Ünsal, 2004). Ayrıca, yaşam doyumu yüksek olan bireyler insanlarla daha iyi iletişim kurabilmekte, olaylar karşısında daha tutarlı davranabilmekte ve mutsuz kişilere oranla sorunlar karşısında daha güçlü kalabilmektedirler (Diener \& Seligman, 2002). Tüm bu etkilerin yanı sıra yaşam doyumu ebeveynlerin yılmazlık düzeyini de olumlu etkilemektedir. Farklı bir ifade ile yılmazlık bireylerin aynı zamanda hayata olumlu bakan sorunlar karşısında yılmayan mücadele eden bireylerdir (Akbar vd., 2014; Bingham, 2004; Demiray, 2019). Yaşam doyum düzeyi yüksek olan ebeveynlerin yılmazlık düzeyleri daha yüksek olacağından yetersizliği olan çocukları ile daha nitelikli ilgileneceklerdir. Bu araştırma sonuçlarına göre babaların, yaşlı ebeveynlerin, gelir ve eğitim düzeyi düşük ve OSB'li çocuğu olan ebeveynlerin hem yaşam doyumlarının hem yılmazlık düzeylerinin daha düşük olduğu görülmektedir. Bu bulgular göz önüne alındığında söz konusu grupların yaşam doyumu ve yılmazlık açısından risk altında oldukları ve mutlaka bu alanlara yönelik olarak gerekli desteklenmeleri gerektiği sonucu varılabilir.

$\mathrm{Bu}$ araştırmanın ebeveynlerin yaşam doyumu ve yılmazlık düzeyleri ile ilgili farklı değişkenlerle ilişkili olarak bilgi edinmede katkıları olmakla birlikte birtakım sınırlılıkları da bulunmaktadır. Araştırmanın sınırlılıkları Bursa ve İzmir ilinde yaşamakta olan ve bu araştırmaya katılmayı kabul eden ebeveynlerle yapılmış olması, özel gereksinim gruplarının ZY ve OSB ile sınırlı olması, özel eğitim rehabilitasyon merkezlerine devam eden çocukların ebeveynlerinden veri elde edilmiş olması, çocukların genel eğitime devam edip etmemesi değişkeninin kontrol edilmemesi, sadece ebeveynlerin öz-bildirimlerinden yola çıkılarak nicel veri toplama araçlarıyla veri toplanması şeklinde sıralanabilir. Araştırmanın sınırlılıklarından yola çıkarak ileri araştırmalara yönelik bazı önerilerde bulunulabilir. Bu araştırma daha geniş bir popülasyonla farklı illerde ve farklı yetersizlik gruplarıyla gerçekleştirilebilir. Bunun yanında farklı yetersizlik grupları ve normal gelişim gösteren çocuğa sahip ebeveynler ile ve bulguların daha derinlemesine anlamak amaçlı karma araştırma yöntemi kullanılarak gerçekleştirebilir. Ayrıca, bu araştırmanın bulguları göz önünde bulundurularak, özellikle yaşam doyumu ve yılmazlık düzeyleri düşük olan dezavantajlı gruplardaki ebeveynlerin yaşam doyumu düzeyleri ve aile yılmazlık düzeylerini destekleyecek programlar düzenlenebilir. 


\section{Kaynaklar}

Ahern, N. R., Kiehl, E. M., Sole, M. L., \& Byers, J. (2006). A review of instruments measuring resilience. Issues in Comprehensive Pediatric Nursing, 29(2), 103-125. https://doi.org/10.1080/01460860600677643

Akandere, M., Acar, M., \& Baştuğ, G. (2009). Zihinsel ve fiziksel engelli çocuğa sahip anne ve babaların yaşam doyumu ve umutsuzluk düzeylerinin incelenmesi [Investigating the hopelessness and life satisfaction levels of the parents with mental disabled child]. Selçuk Üniversitesi Sosyal Bilimler Dergisi, 22, 23-32. http://dergisosyalbil.selcuk.edu.tr/susbed/article/view/268/251

Akbar, M., Akram, M., Ahmed, M., Hussain, M. S., Lal, V., \& Ijaz, S. (2014). Relationship between resilience and life satisfaction among Nomadic. International Journal of Innovation and Applied Studies, 6(3), 515529. https://citeseerx.ist.psu.edu/viewdoc/download?doi=10.1.1.675.1430\&rep=rep1\&type=pdf

Akkök, F. (2003). Farklı özelliğe sahip çocuk aileleri ve ailelerle yapılan çalışmalar. A. Ataman (Ed.), Özel eğitime giriş [Introduction to special education] içinde (ss. 121-142). Gündüz Eğitim ve Yayınc1lık.

Altındağ-Kumaş, Ö., \& Sümer, H. M. (2019). Özel gereksinimli küçük çocuğu olan annelerin öz yetkinlikleri, yılmazlık düzeyleri ve stres düzeyleri arasındaki ilişkilerin belirlenmesi [Identifying the relationships between self-efficacies, resilience levels, and stress levels of mothers of children with special needs]. Kastamonu Eğitim Dergisi, 27(1), 163-173. https://doi.org/10.24106/kefdergi.2445

Aslan, Ç. Ç. (2010). Zihinsel engelli çocuğu olan anne ve babaların psikolojik belirtileri, sosyal destek algıları ve stresle başa çıkma tarzlarının karşılaştırılması [The comparison of the psychological symptoms, perceived social support and ways of coping with stress of the mothers and the fathers who has mentally handicapped children] (Tez Numaras1: 254013) [Yüksek lisans tezi, Maltepe Üniversitesi]. Yükseköğretim Kurulu Ulusal Tez Merkezi.

Avşaroğlu, S., \& Okutan, H. (2018). Zihin engelli çocuğu olan ailelerin yaşam doyumları, iyimserlik ve psikolojik belirti düzeylerinin incelenmesi. [Investigation of life satisfaction optimism and psychological symptom levels of parents with disabled children]. ANAS Sosyal Araştırmalar Dergisi, 7(1), 59-76. https://dergipark.org.tr/tr/download/article-file/578148

Aydın, A., \& Egin, C. T. A. (2018). Zihin engelli, serebral palsili ve otizmli çocuk ebeveynlerinin psikolojik dayanıklılıkları ile ebeveynlik algılarının karşılaştırılması [Comparison of psychological resilience and parental perceptions of parents having children with mentally handicapped, CP and Autism]. Ondokuz Mayıs Üniversitesi Eğitim Fakültesi Dergisi, 37(1), 171-188. https://dergipark.org.tr/tr/download/articlefile/478477

Aykara, A. (2015). Zihinsel engelli kardeşe sahip bireylerin yaşadıkları güçlüklerin sosyal rol kuramı açısından değerlendirilmesi [Assessment of the difficulties of individuals who have mentally disabled siblings according to social role theory]. Toplum ve Sosyal Hizmet, 26(2), 87-104. https://dergipark.org.tr/tr/download/article-file/153095

Aysever, H., \& Demirok, S. M. (2019). Özel gereksinimli çocuğa sahip ebeveynlerin sosyal destek algılarının ve yılmazlık düzeylerinin incelenmesi [Investigating social support perceptions and resilience levels of parents with children with special needs]. Ankara Üniversitesi Ĕ̈itim Bilimleri Fakültesi Özel Ĕ̈itim Dergisi, 20(3), 561-595. https://doi.org/10.21565/ozelegitimdergisi.467417

Bayat, M. (2007). Evidence of resilience in families of children with autism. Journal of Intellectual Disability Research, 51(9), 702-714. https://doi.org/10.1111/j.1365-2788.2007.00960.x 
Bayraklı, H. (2010). Zihinsel engelli ve engelli olmayan çocuğa sahip annelerde yılmazlı̆̆a etki eden değişkenlerin incelenmesi [Investigating the factors affecting resiliency in mothers of mentally retarded and non disabled children] (Tez Numarası: 309512) [Yüksek lisans tezi, Ankara Üniversitesi]. Yükseköğretim Kurulu Ulusal Tez Merkezi.

Bhana, A., \& Bachoo, S. (2011). The determinants of family resilience among families in low-and middle-income contexts: A systematic literature review. South African Journal of Psychology, 41, 131-139. https://doi.org/10.1177/008124631104100202

Bingham, V. (2004). Resiliency and life satisfaction among survivors of early childhood maltreatment [Master's thesis, California State University]. https://search.proquest.com/docview/305036993?pqorigsite $=$ gscholar\&fromopenview $=$ true

Boztaş, Z., \& Tutkun, Ö. F. (2017). Özel gereksinimli çocuğu olan anne-babaların yaşam doyumu düzeyi [Life satisfaction level of parents with special needs child]. Akademik Sosyal Araştırmalar Dergisi, 5(50), 390399. https://asosjournal.com/DergiTamDetay.aspx?ID=12452

Bristol, M. M. (1984). Family resources and successful adaptation in families of autistic children. In E. Schopler \& G. Mesibov (Eds.), The effects of autism on the family (pp. 289-310). Plenum.

Büyüköztürk, Ş. (2014). Sosyal bilimler için veri analizi el kitabı [Manual of data analysis for social sciences]. Pegem Akademi.

Campbell-Sills, L., Forde, D. R., \& Stein, M. B. (2009). Demographic and childhood environmental predictors of resilience in a community sample. Journal of Psychiatric Research, 43(12), 1007-1012. https://doi.org/10.1016/j.jpsychires.2009.01.013

Cavkaytar, A., \& Özen, A. (2010). Aile katılımı ve eğitimi. G. Akçamete (Ed.), Özel eğitim [Special education] içinde (ss. 169-202). Kök Yayıncılık.

Cho, S., \& Kahng, S. K. (2015). Predictors of life satisfaction among caregivers of children with developmental disabilities in South Korea. Asian Social Science, 11(2), 154-166. http://dx.doi.org/10.5539/ass.v11n2p154

Coşkun, A. (2018). Zihinsel ve fiziksel engelli bireylere bakım hizmeti veren aile üyelerinin yaşam doyumu ve bakım yüklerinin karşılaştırılması [Comparison of the life satisfaction and care loads of family members who care service for mentally and physical disabled individuals] (Tez Numaras1: 520826) [Yüksek lisans tezi, Üsküdar Üniversitesi]. Yükseköğretim Kurulu Ulusal Tez Merkezi.

Cummings, S. T., Bayley, H. C., \& Rie, H. E. (1996). Effect of the child's deficiency on the mother: A study of mothers of mentally retarded, chronically III and neurotic chidren. American Journal of Orthopsychiatry, 36(4), 595-608. https://doi.org/10.1111/j.1939-0025.1966.tb02311.x

Çattık, M., \& Aksoy, V. (2018). Gelişimsel yetersizliği olan çocukların ebeveynlerinin sosyal destek, öz yeterlik ve yaşam doyum düzeyleri arasındaki ilişkinin incelenmesi [An examination of the relations among social support, self-efficacy, and life satisfaction in parents of children with developmental disabilities]. Eğitim ve Bilim, 43(195), 65-77. http://dx.doi.org/10.15390/EB.2018.7246

Çengelci, B. (2009). Otizm ve Down Sendromlu çocuğa sahip annelerin kaygı, umutsuzluk ve tükenmişlik duygularının karşılaştırılması [A comparisen of level of anxiety, hopelessness and burnout syndrome of mothers who have children with diagnosis of autism or Down syndrome]. Ege Eğitim Dergisi, 10(2), 123. https://dergipark.org.tr/tr/download/article-file/57030 
Dabrowska, A., \& Pisula, E. (2010). Parenting stress and coping styles in mothers and fathers of pre-school clinical with autism and Down syndrome. Journal of Intellectual Disability Research, 54, 266-280. https://doi.org/10.1111/j.1365-2788.2010.01258.x

Darling, C. A., Senatore, N., \& Strachan, J. (2012). Fathers of children with disabilities: Stress and life satisfaction. Stress and Health, 28, 269-278. https://doi.org/10.1002/smi.1427

Demiray, G. (2019). Özel gereksinimli çocuğu olan ailelerde yaşam kalitesi, umutsuzluk ve yılmazlık arasındaki iliskilerin incelenmesi [Analysis of the relationship between the quality of life, hopelessness and resilience in families of children with disabilities] (Tez Numarası: 597819) [Yüksek lisans tezi, Marmara Üniversitesi]. Yükseköğretim Kurulu Ulusal Tez Merkezi.

Deniz, M. E., Dilmaç, B., \& Arıcak, O. T. (2009). Engelli çocuğa sahip olan ebeveynlerin durumluk sürekli kaygı ve yaşam doyumlarının incelenmesi [An analysis of life satisfaction and state-trait anxiety of the parents with handicapped children]. Uluslararast Insan Bilimleri Dergisi, 6(1), 953-968. https://www.jhumansciences.com/ojs/index.php/IJHS/article/view/727/389

Diener, E., \& Seligman, M. E. P. (2002). Very happy people. Psychological Science, 13(1), 81-84. https://doi.org/10.1111/1467-9280.00415

Diener, E. (2009). Subjective well-being. In E. Dinner (Ed.), The science of well-being; The collected works of Ed Diener, Social indicators research series (1st ed., pp. 11-58). Springer.

Diener, E., Diener, M., \& Diener, C. (1995). Factors prediciting the subjective well-being of nations. Journal of Personality and Social Psychology, 69(5), 851-864. https://doi.org/10.1111/1467-9280.00415

Diener, E., Emmons, R. A., Larsen, R. J., \& Griffin, S. (1985). The satisfaction with life scale. Journal of Personality Assessment, 49(1), 71-75. https://doi.org/10.1207/s15327752jpa4901_13

Girli, A., Yurdakul, A., Sarısoy, M., \& Özekes, M. (1998, Aralık 1-4). Zihinsel engelli ve otistik çocukların anne babalarına yönelik grup danışmanlığının depresyon, benlik saygısı ve tutumları üzerine etkisi [The effect of group counseling on parents of mentally disabled and autistic children on depression, self-esteem and attitudes] [Sözlü bildiri]. 10. Ulusal Psikoloji Kongresi, Ankara, Türkiye.

Greeff, A. P., \& Walt, K. J. (2010). Resilience in families with an autistic child. Education and Training in Autism and Developmental Disabilities, 45(3), 347-35. https://www.jstor.org/stable/23880109?seq=1

Gülald1, D. (2010). Erken çocuklukta Serebral Palsili ve otistik çocuk annelerinin ebeveyn stres düzeylerinin yasam doyumlart ile ilişkisinin incelenmesi [Examining the relationship between parental stress levels and life satisfaction of mothers with cerebral palsy and autistic children in early childhood]. (Tez Numarası: 278757) [Yüksek lisans tezi, Maltepe Üniversitesi]. Yükseköğretim Kurulu Ulusal Tez Merkezi.

Ha, J. H., Hong, J., Seltzer, M. M., \& Greenberg, J. S. (2008). Age and gender differences in the well-being of midlife and aging parents with children with mental health or developmental problems: Report of a national study. Journal of Health and Social Behavior, 49, 301-316. https://doi.org/10.1177/002214650804900305

Hartley, S. L., Papp, L. M., Blumenstock, S. M., Floyd, F., \& Goetz, G. L. (2016). The effect of daily challenges in children with autism on parents' couple problem-solving interactions. Journal of Family Psychology, 30(6), 732-742. https://doi.org/10.1037/fam0000219 
Hastings, R. P., Allen, R., McDermott, K., \& Still, D. (2002). Factors related to positive perceptions in mothers of children with intellectual disabilities. Journal of Applied Research in Intellectual Disabilities, 15(3), 269275. https://doi.org/10.1046/j.1468-3148.2002.00104.x

Hayes, S. A., \& Watson, S. L. (2013). The impact of parenting stres: A meta-analysis of studies comparing the experience of parenting stress in parents of children with and without autism spectrum disorder. Journal of Autism and Developmental Disorders, 43(3), 629-642. https://doi.org/10.1007/s10803-012-1604-y

Heiman, T. (2002). Parents of children with disabilities: Resilience, coping, and future expectattions. Journal of Developmental and Physical Disabilities, 14(2), 159-171. https://doi.org/10.1023/A:1015219514621

Henderson, N., \& Milstein, M. M. (1996). Resiliency in schools: Making it happen for students and educators. Corwin Press.

Hisoğlu, A. (2018). Otizm spektrum bozukluğu tanilı çocukların ebeveynlerinde algllanan sosyal destek ve problem çözme becerilerinin yaşam doyumuna etkisi [Perceived social support in parents of children with autism spectrum disorder and the effect of problem solving skills on life satisfaction] (Tez Numaras1: 486073) [Yüksek lisans tezi, Üsküdar Üniversitesi]. Yükseköğretim Kurulu Ulusal Tez Merkezi.

Huang, Y. P., Chang, M. Y., Chi, Y. L., \& Lai, F. C. (2014). Health-related quality of life in fathers of children with or without developmental disability: The mediating effect of parental stress. Quality of Life Research, 23, 175-183. https://doi.org/10.1007/s11136-013-0469-7

İnce, Z. E., \& Tüfekci, F. G. (2015). Engelli çocuğu olan ebeveynlerde evlilik uyumu ve yaşam doyumunun değerlendirilmesi ve etkileyen faktörlerin belirlenmesi [Evaluation of marital adjustment and life satisfaction in parents with children with disabilities and determination of the affecting factors]. Gümüşhane Üniversitesi Sağllk Bilimleri Dergisi, 4(1), 102-112. https://dergipark.org.tr/tr/download/article-file/220169

Kadı, S. (2016). Zihinsel engellilerin eğitimi bilim dalı çoklu yetersizliğe sahip çocuğu olan ebeveynlerin yılmazlık düzeylerinin çeşitli değişkenler açısından belirlenmesi [Determining the resilience levels of parents with children with multiple disabilities in the branch of science education of the mentally handicapped in terms of various variables] (Tez Numarasi: 418151) [Yüksek lisans tezi, Abant İzzet Baysal Üniversitesi]. Yükseköğretim Kurulu Ulusal Tez Merkezi.

Kaner, S. (2004). Engelli çocukları olan ana-babaların algıladıkları stres, sosyal destek ve yaşam doyumlarının incelenmesi (Rapor Numarası: 2001-0901-007). Ankara Üniversitesi Bilimsel Araştırma Projeleri. https://dspace.ankara.edu.tr/xmlui/bitstream/handle/20.500.12575/68118/2668.pdf?sequence=1\&isAllo wed $=\mathrm{y}$

Kaner, S. (2009). Zihin engelli çocukların duygusal ve davranışsal problemlerinin değerlendirilmesinde anne baba ve ögretmen tutarlılığı [Consistency of parents' and teachers' assessment of emotional and behavioral problems in children with mentally retarded]. Ankara Üniversitesi Ĕgitim Bilimleri Fakültesi Dergisi, 42(2), 239-263. http://dergiler.ankara.edu.tr/dergiler/40/1223/13981.pdf

Kaner, S., \& Bayraklı, H. (2010). Aile Yılmazlık Ölçeği: Geliştirilmesi, geçerliği ve güvenirliği [Family Resilience Scale: Development, reliability and validity]. Ankara Üniversitesi Eğitim Bilimleri Fakültesi Özel Ĕgitim Dergisi, 11(2), 47-62. https://doi.org/10.1501/Ozlegt_0000000151

Kaner, S., Bayraklı, H., \& Güzeller, C. O. (2011). Anne-babaların yılmazlık algılarının bazı değişkenler açısından incelenmesi [Investigating perception of parental resilience in terms of some variables]. Ankara Üniversitesi Eğitim Bilimleri Fakültesi Dergisi, $12(2), \quad$ 63-78. https://doi.org/10.1501/Ozlegt 0000000161 
Kantar, Ö. (2014). Engelli çocuğu olan ebeveynlerde bilişsel değerlendirmenin, gelişme-büyümenin yaşam doyumu ile ilişkisi [The relationship between cognitive appraisal, flourishing and the satisfaction with life in parents of disabled children] (Tez Numarası: 385505) [Yüksek lisans tezi, İstanbul Bilim Üniversitesi]. Yükseköğretim Kurulu Ulusal Tez Merkezi.

Karande, S., \& Kulkarni, S. (2009). Quality of life of parents of children with newly diagnosed specific learning disability. Journal of Postgraduate Medicine, 55(2), 97-103. https://doi.org/10.1093/tropej/fmn099

Karasar, N. (2012). Bilimsel araştırma yöntemi [Scientific research methods] (23. baskı). Nobel Yayın Dağııım.

Kaya, Ö. (2015). Otizm spektrum bozukluğu olan bireyler ve aileleri. A. Cavkaytar (Ed.), Otizm spektrum bozukluğu [Autism spectrum disorder] içinde (ss. 291-309). Engelli ve Yaşl1 Hizmetleri Genel Müdürlüğü.

Kocakaya, R. (2017). Engelli üyeye sahip ailelerdeki bireylerin psikolojik dayanıkllliğ ile algllanan aile işlevselliği arasindaki ilişki [Relationship between psychological resilience and perceieved family functioning of individuals in families with disabled members] (Tez Numarası: 468775) [Yüksek lisans tezi, Yıldırım Beyazıt Üniversitesi]. Yükseköğretim Kurulu Ulusal Tez Merkezi.

Kumbasar, A. (2016). İşitme engelli ve engelli olmayan çocuklara sahip ailelerde sosyal destek algısl, yllmazlık ve tükenmişlik düzeylerinin incelenmesi [The examination of social support perceptions and burnout and resiliency levels of families with and without hearing impaired children] (Tez Numaras1: 445331) [Yüksek lisans tezi, Hacettepe Üniversitesi]. Yükseköğretim Kurulu Ulusal Tez Merkezi.

Küçüker, S. (1993). Özürlü çocuk ailelerine yönelik psikolojik danışma hizmetleri [Psychological counseling services for families of disabled children]. Ankara Üniversitesi Ĕ̆itim Bilimleri Fakültesi Özel Ĕgitim Dergisi, 1(3), 23-29. http://dergiler.ankara.edu.tr/dergiler/39/41/354.pdf

Lee, G. K., Lopata, C., Volker, M. A., Thomeer, M. L., Nida, R. E., Toomey, J. A., Chow, S. Y., \& Smerbeck, A. M. (2009). Health-related quality of life of parents of children with high-functioning autism spectrum disorders. Focus on Autism and Other Developmental Disabilities, 24(4), 227-239. https://doi.org/10.1177/1088357609347371

Lloyd, T., \& Hastings, R. (2009). Hope as a psychological resilience factor in mothers and fathers of children with intellectual disabilities. Journal of Intellectual Disability Research, 53(12), 957-968. https://doi.org/10.1111/j.1365-2788.2009.01206.x

Lu, M., Wang, G., Lei, H., Shi, M., Zhu, R., \& Jiang, F. (2018). Social support as mediator and moderator of the relationship between parenting stress and life satisfaction among the Chinese parents of children with ASD. Journal of Autism and Developmental Disorders, 48(1), 1181-1188. https://doi.org/10.1007/s10803-017-3448-y

Marcus, L. M., Kunce, L. J., \& Schopler, E. (2005). Working with families. In F. R. Volkmar, R. Paul, A. Klin \& D. Kohens (Eds.), Handbook of autism and pervasive developmental disabilities, Volume 2 (ss. 10551087). John Wiley \& Sons.

McConnell, D., Savage, A., \& Breitkreuz, R. (2014). Resilience in families raising children with disabilities and behavior problems. Research in Developmental Disabilities, 35(4), 833-848. https://doi.org/10.1016/j.ridd.2014.01.015

Moh, T. A., \& Magiati, I. (2012). Factors associated with parental stress and satisfaction during the process of diagnosis of children with autism spectrum disorders. Research in Autism Spectrum Disorders, 6, 293 303. https://doi.org/10.1016/j.rasd.2011.05.011 
Nergiz, H. (2013). Görme engelli çocuk ebeveynlerinin yaşadığı güçlüklerin belirlenmesi ve tükenmişlik ile yaşam doyumuna yönelik yordayıcı değişkenler [Assesting experienced difficulties of parents who have a visually impaired children and predictors of life satisfaction and burnout] (Tez Numaras1: 339050) [Yüksek lisans tezi, Hacettepe Üniversitesi]. Yükseköğretim Kurulu Ulusal Tez Merkezi.

Ohaeri, J. U. (2003). The burden of caregiving in families with a mental illness: A review of 2002. Current Opinion in Psychiatry, 16(4), 457-465. https://doi.org/10.1097/00001504-200307000-00013

Olsson, C. A., Bond, L., Burns, J. M., Vella-Brodrick, D. A., \& Sawyer, S. M. (2003). Adolescent resilience: A concept analysis. Journal of Adolescence, 26(1), 1-11. https://doi.org/10.1016/S0140-1971(02)00118-5

Openshaw, K. P. (2011). The relationship between family functioning, family resilience, and quality of life among vocational rehabilitation clients [Doctoral dissertation, Utah State University Logan]. https://digitalcommons.usu.edu/cgi/viewcontent.cgi?article=2084\&context=etd

Palancı, M. (2018). Engelli çocuğa sahip anne babaların aile yılmazlığı, öznel iyi oluş ve evlilik uyumlarının psikososyal yeterlikler ile yordanması [A prediction of the resilience, subjective well-being and marital adjustment of the parents having children with disabilities based on psycho-social competence]. Eğitim ve Bilim, 43(1939), 217-236. http://dx.doi.org/10.15390/EB.2017.4384

Patterson, J. (2002). Integrating family resilience and family stress theory. Journal of Marriage and Family, 64(2), 349-360. https://doi.org/10.1111/j.1741-3737.2002.00349.x

Pavot, W., Diener, E, Colvin, R., \& Sandvik, E. (1991). Further validation of the satisfaction with life scale: Evidence for the cross method convergence of well-being measures. Journal of Personality Assessment 57(1), 149-161. https://doi.org/10.1207/s15327752jpa5701_17

Plumb, J. C. (2011). The impact of social support and family resilience on parental stress in families with a child diagnosed with an autism spectrum disorder [Doctoral dissertation, University of Pennsylvania]. https://repository.upenn.edu/cgi/viewcontent.cgi?article=1015\&context=edissertations_sp2

Pottie, C. G., \& Ingram, K. M. (2008). Daily stress, coping, and well-being in parents of children with autism: A multi level modeling approach. Journal of Family Psychology, 22(6), 855-864. https://doi.org/10.1037/a0013604

Pozo, P., Sarriá, E., \& Brioso, A. (2014). Family quality of life and psychological well-being in parents of children with autism spectrum disorders: A double ABCX model. Journal of Intellectual Disability Research, 58(5), 442-458. https://doi.org/10.1111/jir.12042

Roach, M. A., Orsmond, G. I., \& Barratt, M. S. (1999). Mothers and fathers of children with Down syndrome: Parental stress and involvement in child care. American Journal on Mental Retardation, 104(5), 422-436. https://meridian.allenpress.com/ajidd/article-abstract/104/5/422/665/Mothers-and-Fathers-of-ChildrenWith-Down-Syndrome?redirectedFrom=fulltext

Ryan, L., \& Caltabiano, M. L. (2009). Development of a New Resilience Scale: The Resilience in Midlife Scale (RIM Scale). Asian Social Science, 5(11), 39. http://dx.doi.org/10.5539/ass.v5n11p39

Sarıkaya, S. (2011) Zihinsel engelli çocuğu olan ebeveynlerin stresle başa çıkma düzeylerinin ve yaşam doyumlarinin incelenmesi [The investigation of coping strategies and life satisfaction levels of parents with mentally retarded children] (Tez Numarasi: 286525) [Yüksek lisans tezi, Adnan Menderesi Üniversitesi]. Yükseköğretim Kurulu Ulusal Tez Merkezi. 

DOYUMU VE AILE YILMAZLIK DÜZEYLERININ İNCELENMESI

Sari, T. (2014). Öznelik kapasitesi bağlamında biyolojik annelik: Üremeye yardımcı teknolojileri kullanan kadinlarin deneyimleri [Biological motherhood in terms of the capacity for subjectivity: Experiences of women who use assisted reproductive technology] (Tez Numarasi: 366603) [Yüksek lisans tezi, Adnan Menderes Üniversitesi]. Yükseköğretim Kurulu Ulusal Tez Merkezi.

Satılmış, S. (2020). Otizm spektrum bozukluğu tanısı almış çocukların annelerinde psikolojik dayanıkllık, yaşam doyumu ve depresyon arasindaki ilişsinin incelenmesi [Investigation of relationship between psychological resilience, life satisfaction and depresion in authism spectrum disorder's mother] (Tez Numarasi: 386525) [Yüksek lisans tezi, Yakın Doğu Üniversitesi]. Yükseköğretim Kurulu Ulusal Tez Merkezi.

Saunders, B. S., Tilford, J. M., Fussell, J. J., Schulz, E. G., Casey, P. H., \& Kuo, D. Z. (2015). Financial and employment impact of intellectual disability on families of children with autism. Families, Systems, \& Health, 33(1), 36-45. https://doi.org/10.1037/fsh0000102

Schaaf, R. C., Toth-Cohen, S., Johnson, S. L., Outten, G., \& Benevides, T. W. (2011). The everyday routines of families of children with autism: Examining the impact of sensory processing difficulties on the family. Autism, 15(2), 1-17. https://doi.org/10.1177/1362361310386505

Seltzer, M. M., Greenberg, J. S., Floyd, F. J., Pettee, Y., \& Hong, J. (2001). Life course impacts of parenting a child with a disability. American Journal on Mental Retardation, 106(3), 265-286. https://doi.org/10.1352/0895-8017(2001)106<0265:LCIOPA>2.0.CO;2

Seltzer, M. M., Krauss, M. W., \& Tsunematsu, N. (1993). Adults with Down syndrome and their aging mothers: Diagnostic group differences. American Journal on Mental Retardation, 97(5), 496-508. https://pubmed.ncbi.nlm.nih.gov/8461121/

Sirgy, J. M., Michalos, A. C., Ferris, A., Easterlin, R., Patrick, D., \& Pavot, W. (2006). The quality-of-life (QoL) research movement: Past, present, and future. Social Indicators Research, 76, 343-466. https://doi.org/10.1007/s11205-005-2877-8

Sloper, P., \& Turner, S. (1993). Risk and resistance factors in the adaptation of parents of children with severe physical disability. Journal of Child Psychology and Psychiatry, 34(2), 167-188. https://doi.org/10.1111/j.1469-7610.1993.tb00978.x

Sloper, P., Knussen, C, Turner, S., \& Cunningham, C. (1991). Factors related to stress and satisfaction with life in families of children with Down Syndrome. Journal of Child Psychology Psychiatry, 32(4), 655-676. https://doi.org/10.1111/j.1469-7610.1991.tb00342.x

Smith, T. B., Matthew, N. I., Oliver, M. A., \& Innocenti, M. S. (2001). Parenting stress in families of children with disabilities. American Journal of Orthopsychiatry, 71(2), 257-261. https://doi.org/10.1177/1053451217712956

Steger, M. F., Frazier, P., Oishi, S., \& Kaler, M. (2006). The meaning in life questionnaire: Assessing the presence of and search for the meaning in life. Journal of Counseling Psychology, 53, 80-93. https://doi.org/10.1037/0022-0167.53.1.80

Şafak, P. (2012). A ̈̆ır ve çoklu yetersizliği olan çocukların eğitimi [Education of children with severe and multiple disabilities]. Vize yayınc1lik. 

DOYUMU VE AILE YILMAZLIK DÜZEYLERININ İNCELENMESI

Şanlı, D., \& Öztürk, C. (2015). Anne babaların çocuk yetiştirme tutumları ve tutumlar üzerine kültürün etkisi [Contraceptive methods, pregnancy and breastfeeding after organ transplantation]. Dokuz Eylül Üniversitesi Hemşirelik Fakültesi Elektronik Dergisi, 8(4), 240-246. https://dergipark.org.tr/tr/download/article-file/753171

Tabachnick, B. G., \& Fidell, L. S. (2013). Using multivariate statistics. Allyn and Bacon.

Taşdemir, F. (2013). Görme engelli öğrenci annelerinin yllmazllk özelliklerinin incelenmesi (İstanbul ili örneği) [The examination of the indomitableness characteristics of the sight disabled students mothers-Istanbul Sample] (Tez Numarası: 350942) [Yüksek lisans tezi, Yeditepe Üniversitesi]. Yükseköğretim Kurulu Ulusal Tez Merkezi.

Telman, N., \& Ünsal, P. (2004). Çalı̧san memnuniyeti [Employee satisfaction]. Epsilon Yayınevi.

Tuğrul, Y. G. (2019). Toplumsal cinsiyet bağlamında kadınların annelik deneyimleri üzerine bir saha çalışması [A gender-based field study on the motherhood experiences of women in the context of gender]. Toplum ve Kültür Araştırmaları Dergisi, 3, 71-90. https://dergipark.org.tr/tr/download/article-file/837784

Turan, N. (2017). Otistik çocuğa sahip ailelerin yllmazlı düzeylerinin incelenmesi [Investigation of resilience levels of families with autistic children] (Tez Numarasi: 486218) [Yüksek lisans tezi, Hasan Kalyoncu Üniversitesi]. Yükseköğretim Kurulu Ulusal Tez Merkezi.

Turnbull, A., Turnbull, R., Erwin, E., \& Soodak, L. (2006). Families, professionals, and exceptionality: Positive outcomes through partnerships and trust. Pearson.

Uğuz, Ş., Toros, F., İnanç, B., \& Çolakkadıoğlu, O. (2004). Zihinsel ve/veya bedensel engelli çocukların annelerinin anksiyete, depresyon ve stres düzeylerinin belirlenmesi [Assessment of anxiety, depression and stres levels of mothers of handicapped children]. Klinik Psikiyatri, 7(1), 42-47. https://jag.journalagent.com/kpd/pdfs/KPD_7_1_42 47.pdf

Upadhyaya, G., \& Havalappanavar, N. (2008). Stress in parents of the mentally challenged. Journal of the Indian Academy of Applied Psychology, 34(Special Issue), 53-59. http://medind.nic.in/jak/t08/s1/jakt08s1p53.pdf

Vara, Ş. (1999). Yoğun bakım hemşirelerinde iş doyumu ve genel yaşam doyumu arasındaki ilişskilerin incelenmesi [A Study on the factors affecting the job satisfaction and the life satisfaction of the nurses working at intensive care services] (Tez Numarasi: 86633) [Yüksek lisans tezi, Ege Üniversitesi]. Yükseköğretim Kurulu Ulusal Tez Merkezi.

Walsh F. (2003). Family Resilience: A framework for clinical practice. Family Process, 42(1), 1-18. https://doi.org/10.1111/j.1545-5300.2003.00001.x

Walsh, F. (2006). Strengthening family resilience. Guilford Publications.

Yavuz, S. (2016). Normal gelişim gösteren çocuğa sahip ebeveynler ile zihinsel engelli çocuğa sahip ebeveynlerin evlilik uyuти ve yaşam doyumu düzeylerinin incelenmesi [Marital adjustments and examination of life satisfaction levels of parents with mentally deficient and healthy children] (Tez Numaras1: 435241) [Yüksek lisans tezi, Haliç Üniversitesi]. Yükseköğretim Kurulu Ulusal Tez Merkezi. 


\section{Ankara University Faculty of \\ Educational Sciences Journal of \\ Special Education}

2021, 22(4), 799-825
RESEARCH

Recieved Date: 23.04 .20

Accepted Date: 05.02.21

OnlineFirst: 22.02 .21

\title{
An Analysis on the Life Satisfaction and Resilience Levels of Parents of Individuals with Autism Spectrum Disorder and Intellectual Disabilities
}

\author{
Mehmet Yavuz
}

Özlem Gümüşkaya ${ }^{D 2}$

\begin{abstract}
Introduction: In this study, life satisfaction and family resilience levels of parents of children with autism spectrum disorder (ASD) and intellectual disabilities (ID) were examined.

Method: Relational screening model was used in the study. The participants of the study consisted of 309 parents from Izmir and Bursa. The data were obtained using the Family Resilience Assessment Scale and Life Satisfaction Scale. t-test, ANOVA, Tukey HSD Test and Pearson correlation analysis were used in the analysis of the data.

Findings: The findings on the variables regarding parents' life ability showed that mothers, young parents, those with high income levels, those with high educational levels, and parents who had children with ID had higher life satisfaction levels than the groups they were compared with. Significant differences were observed in family resilience levels with respect to the overall scale scores regarding gender, bellicosity, mothers in the commitment to life and self-control subdimensions, young parents in the self-efficacy subdimension, high income parents in the self-efficacy subdimension, high level of education in the bellicosity subdimension, overall scale score in the disability type of their children, children with ID in the bellicosity, self-efficacy and commitment to life subdimensions. There was a positive relationship between life satisfaction and family resilience, and all subdimensions.
\end{abstract}

Discussion: The findings of this study were discussed in line with the literature. According to the results of the research, it was observed that individuals with high life satisfaction also have high family resilience levels. Individuals with a high level of satisfaction with life look at life more positively, experience less stress and overcome the problems they encounter more easily.

Keywords: Family, life satisfaction, family resilience, autism spectrum disorder, intellectual disability.

To cite: Yavuz, M., \& Gümüşkaya, Ö. (2021). An analysis on the life satisfaction and resilience levels of parents of individuals with autism spectrum disorder and intellectual disabilities. Ankara University Faculty of Educational Sciences Journal of Special Education, 22(4), 799-825. https://doi.org/10.21565/ozelegitimdergisi.726030

${ }^{1}$ Corresponded Author: Asisst. Prof., Trakya University, E-mail: mehmetyavuz23@gmail.com, https://orcid.org/0000-00030762-1611

${ }^{2}$ Asisst. Prof., Sakarya University, E-mail: okaya@sakarya.edu.tr, https://orcid.org/0000-0002-1626-7637 


\section{Introduction}

When a child with a disability joins the family, it significantly affects the family's lifestyle (Akkök, 2003; Ohaeri, 2003; Walsh, 2006) and the parents' psychology (Cavkaytar \& Özen, 2010). This situation has various reasons. First of all, while parents expect their child to be healthy, the child not being born healthy causes disappointment for them. Additionally, the inability to explain this new situation to those around them significantly affects the parents' psychological state (Akkök, 2003; Cavkaytar \& Özen, 2010). Also, the parents having insufficient information about the child's disability and the child having additional health problems affect psychological wellbeing (Cavkaytar \& Özen, 2010; Saunders et al., 2015) because health problems bring an additional burden to the family budget. The family should go to the hospital frequently and interact with many different experts. These types of problems also cause parents to make time for each other isolating from their social circle (Patterson, 2002; Schaaf et al., 2011). All of the aforementioned problems can cause stress (Darling et al., 2012; Kaner et al., 2011; Ohaeri, 2003; Patterson, 2002; Seltzer et al., 2001), anxiety (Kaner, 2009), low selfrespect (Girli et al., 1998), more health problems and depression over time for parents (Roach et al., 1999).

One of the variables that affect how parents cope with these problems is resilience (Altındağ-Kumaş \& Sümer, 2019; Olsson et al., 2003; Patterson, 2002). Resilience is the individual's ability to find coping strategies for difficult or sudden living conditions (Ahern et al., 2006). Family resilience is the family's ability to overcome difficult life conditions and problems and return to a balanced state once again (Patterson, 2002). Resilience allows individuals to adapt to daily life and cope with problems when a stressful situation appears. Variables such as having a strong social support (Bristol, 1984), being together and spirituality strongly affect family resilience (Bayat, 2007). Parents with high resilience levels displayed fewer depressive behaviors; were happier in their marriages (Bristol, 1984), and considered it easier to accept their child with disability (Bayat, 2007; Bristol, 1984).

Another variable that allows parents to cope with problems such as stress, depression is their level of life satisfaction. Life satisfaction is the general judgment and evaluation of a person's life (Diener, 1985). Life satisfaction of the individual is related to psychological characteristics such as how pleased they are with their overall life, their satisfaction and state of morale (Vara, 1999). An individual with high life satisfaction is an individual who is modest, intelligent, healthy and who has positive desires (Sirgy et al., 2006). In addition, he/she is happy, more open to social life, more enduring in the face of problems and can give appropriate reactions, distant from feelings such as being suicidal. Individuals have high interpersonal relationships, do not have problems in their marriages, and can easily cope with marital problems (Sirgy et al., 2006).

In literature, there are various studies regarding the resilience levels of parents of individuals with disabilities. The resilience levels of parents of children with intellectual disabilities (ID), physical disabilities (PD), and learning disabilities (LD) were examined (Heiman, 2002), with ID (Lloyd and Hastings, 2009), with and without ID Bayrakl1, 2010), with Autism Spectrum Disorder (ASD) (Plumb, 2011), with ID who displayed normal development (Kaner et al., 2011), with ASD, ID, cerebral palsy and other disabilities (McConnell et al., 2014), with hearing disabilities displaying normal development (Kumbasar, 2016), with multiple disabilities (Kad1, 2016), and parents of children with ASD were examined (Turan, 2017). Moreover, there are various studies investigating the life satisfaction of parents of children with disabilities. For example, life satisfaction levels of parents of children with Down Syndrome were examined by Sloper et al. (1991), with ID and PD by Akandere et al. (2009), with cerebral palsy and ASD by Gülaldı (2010), with ID by Sarıkaya (2011), with disabilities by Darling et al. (2012), with ASD, ID, physical disabilities and Down syndrome by Kantar (2014), with and without developmental disabilities by Huang et al. (2014), with ASD and ID by Cho and Kahng (2015), with ID and typical development by Yavuz (2016), with ASD, ID and other developmental disabilities by Çattık and Aksoy (2018), and parents of children with ID were examined by Avşaroğlu and Okutan (2018), a limited number of studies examined the relationship between family resilience of children with disabilities and their life satisfaction Palanc1 (2018) and Openshaw (2011) examined the relationship between life satisfaction of individuals with disabilities and family resilience. Demiray (2019) examined the relationship between the life quality of parents of children with special needs and family resilience.

This study may play a significant role in terms of providing information about the levels of life satisfaction and family resilience of the parents of children with ASD and ID. Therefore, the study will guide the organization of training events and support services for parents. We also believe that the results can be employed to determine the direction of education provided to children with ASD and ID. Additionally, it is noted that this study is important in terms of providing data for future studies conducted with parents of children with ASD and ID. Thus, 

WITH AUTISM SPECTRUM DISORDER AND INTELLECTUAL DISABILITIES

the aim of the study is to examine life satisfaction and family resilience levels of parents of children with ASD and ID. For this purpose, the following research questions guided the study:

1. Is there a significant difference between parents' life satisfaction and family resilience levels with respect to the variables such as gender, age, income rate, level of education and the children's disability type?

2. Is there a relationship between the parents' family resilience levels and life satisfaction levels?

\section{Method}

In this study relational screening model was used. The participants of the study consisted of 309 parents of children attending 15 Special Education and Rehabilitation Centers (SERC) in Izmir and Bursa during 20192020 academic year. $122(39.5 \%)$ of the parents were male and $187(60.5 \%)$ were female. 42 of the parents (13.59\%) were below the age of 30, 69 (22.33\%) between 31-40, 107 (34.63\%) 41-50, and 91 (29.45\%) over 51. A total of 88 parents (28.5\%) had an income of 2500 Turkish Liras (TL) and below, 105 (34.0\%) 2501-3500 TL, $61(19.7 \%)$ 3501-4500 TL, $30(9.7 \%) 4501-5500$ TL, and 25 (8.1\%) 5501 and above. In terms of parents' level of education, $86(27.8 \%)$ had primary education, $79(25.6 \%)$ secondary education, $80(25.9 \%)$ undergraduate, and 64 $(20.7 \%)$ postgraduate education degree. When the type of disability of the children was evaluated, $139(44.98 \%)$ had a child with ID, and $170(55.02 \%)$ with ASD. In order to collect data for the study, a demographic information form, the Family Resilience Assessment Scale (FRAS) developed by Kaner \& Bayrakl1 (2010), the Life Satisfaction Scale developed by Diener et al. (1985) and adapted to Turkish and validity and reliability of which were performed by Dağlı \& Baysal (2016) were used. Special education and rehabilitation centers were visited to collect data as well. Parents were contacted face to face or on the phone and the importance of the study was explained. Information about how to fill in the scales was given during the interviews to the volunteer parents. IBM SPSS 24.0 package program was used for data analysis. Descriptive statistics, independent sample t-test, oneway ANOVA, and Tukey HSD Test were employed. Pearson correlation analysis was conducted to examine the relationship between Family Resilience and Life Satisfaction.

\section{Results}

The parents' life satisfaction levels showed a significant difference in terms of gender in favor of the mothers. There was a significant difference in terms of children's disability type in favor of the children with ID. Regarding the age variable, a significant difference was observed between parents below the age of 30 and between the ages 31-40, in favor of the parents below the age of 30; between those below the age of 30 and over the age of 51 , in favor of those below the age of 30; and those between the ages of 41-50 and over the age of 51 in favor of the parents between the ages of 41-50. In terms of income, a significant difference was observed between parents with an income of $2500 \mathrm{TL}$ and lower and an income between 3501-4500 TL in favor of the parents with an income between 3501-4500 TL; between parents with an income of $2500 \mathrm{TL}$ and lower and an income between 4501 $5500 \mathrm{TL}$, in favor of the parents with an income between 4501-5500 TL. A significant difference in terms of parents' level of life satisfaction and the level of education variable was observed, between primary education and postgraduate education, in favor of postgraduate education.

The parents' family resilience levels show a significant difference in favor of the mother, regarding the gender variable in the overall scale results. Significant differences in favor of the mothers were also observed in the bellicosity, commitment to life and self-control subdimensions of the scale. A significant difference in terms of the age was not observed. Significant differences were not found in the bellicosity, commitment to life and selfcontrol subdimensions of the scale. A significant difference in the self-efficacy subdimension was found. A significant difference between parents under the age of 30 and over the age of 51 was found in favor of the parents under the age of 30 in the self-efficacy subdimension.

In terms of the type of disability of the children, a significant difference was found in favor of children with ID according to the overall scale results. A significant difference in favor of children with ID was also found in the bellicosity, self-efficacy and commitment to life subdimensions of the scale. No significant differences were observed in the self-control dimension. In terms of the income, a significant difference was not found in the overall scale results. Significant differences were not observed in the bellicosity, commitment to life and self-control subdimensions of the scale either. A significant difference was observed in the self-efficacy subdimensions between parents with an income of $2500 \mathrm{TL}$ and lower and parents with an income between 3501-4500 TL in favor of the parents with an income between 3501-4500 TL. 
In terms of low levels of education attainment, a significant difference was not seen in the overall scale results. Significant differences were not observed in the self-efficacy, commitment to life and self-control subdimensions of the scale. A significant difference in the bellicosity subdimension was observed. In the bellicosity subdimension, a significant difference was observed between primary and undergraduate education levels, in favor of the ones with an undergraduate level education. A significant difference was not observed between other levels of education. A positive relationship was found between life satisfaction $(r=626, p<.01)$ and family resilience. In addition, a positive relationship was observed between life satisfaction and the bellicosity $(r=580, p<.01)$, self-efficacy $(r=524, p<.01)$, commitment to life $(r=633, p<.01)$, and self-control $(r=536$, $p<.01)$ subdimensions of the Family Resilience Assessment Scale.

\section{Discussion}

The mothers' life satisfaction levels were significantly higher than those of fathers'. There were some contradictory results between our study and the literature. Akandere et al. (2009) and Sarkaya (2011) found that the life satisfaction levels of fathers were higher. Some studies showed a statistically significant difference in the life satisfaction levels in terms of the parents' gender (Deniz et al., 2009; Diener et al. 1995; Hisoğlu, 2018; İnce \& Tüfekci, 2015; Kaner, 2004; Kantar, 2014; Karande \& Kulkarni, 2009; Nergiz, 2013). On the other hand, studies indicating higher stress levels and depressive results for mothers were also found in the literature because of the responsibility of childcare highly given to mothers (Cummings et al., 1996). Accordingly, observing high life satisfaction levels for the mothers might be the result of maternal instinct. When the relevant literature was examined, some studies indicated that "mother-child relationship is stronger than the relationship between spouses" (Şanlı \& Öztürk, 2015). It is believed that the life satisfaction levels were observed higher in mothers within the scope of this study since mothers accepted their children more due to the close bond between the mother and the child.

When the parents' levels of life satisfaction were evaluated with regards to the age variable, younger parents had higher levels of life satisfaction. Various studies revealed contradictory results. Akandere et al. (2009) and Sarkaya (2011) found that as the parents' age increased, the level of life satisfaction increased. In some studies, a significant relationship between the parents' level of life satisfaction and the age variable was observed (Boztaş \& Tutkun, 2017; Çattık \& Aksoy, 2018; Gülald1, 2010; Huang et al., 2014; Kantar, 2014; Lee et al., 2009; Satılmış, 2020). According to the results of the present study, the parents in the younger age groups had higher levels of life satisfaction because they had more positive and hopeful perspectives on life. Seltzer et al. (1993) found that young mothers who had a child with Down syndrome were less stressed, and had more positive family relationships, and were more likely to refrain from the conflict.

Parents with high income had higher levels of life satisfaction than parents with other income levels. In the literature review, we found studies supporting the results of the present study stating that income rate increases life satisfaction (Akandere et al., 2009; Diener, 2009; İnce \& Tüfekci, 2015; Lu et al., 2018; Sarıkaya, 2011; Yavuz, 2016). On the other hand, in the studies conducted by Çattık \& Aksoy (2018) and Satılmış (2020), they did not observe a significant relationship between income rate and life satisfaction. According to the results of this study, as income rate increased, life satisfaction increased as well. Income rate is one of the predictors of life satisfaction. When the individual's income rate is high, they can provide good education and care opportunities both for the child with disabilities and themselves. Thus, they will have less stress and anxiety. The levels of life satisfaction will increase as stress and anxiety decrease.

Parents with high levels of education had high life satisfaction. When the literature was examined, some studies were found to reveal parallel results with the results of the present study (Akandere et al., 2009; Coşkun, 2018; Diener, 2009; Gülald1, 2010; Sarıkaya, 2011). On the other hand, there are also studies that report life satisfaction does not differ according to the level of education (Çattık \& Aksoy, 2018; Kantar, 2014; Karande \& Kulkarni, 2009; Lee et al., 2009; Pozo et al., 2014; Satılmış, 2020). According to the results of this study, parents with high levels of education had higher levels of life satisfaction. It is believed that this result can be explained by parents with a high level of education coping with problems easier because they can attain information about their children's disabilities more easily, have easier access to information and sources about their children's health problems, and can attend appropriate education environments. In literature, it is seen that parents with a high level of education and with a child with ID use problem-solving strategies better (Sarkkaya, 2011) and are less stressed (Smith et al., 2001). To summarize, a positive relationship was found between the parents' level of education and life satisfaction (Steger et al., 2006). 

WITH AUTISM SPECTRUM DISORDER AND INTELLECTUAL DISABILITIES

A significant difference was found in the parents' levels of life satisfaction, in favor of parents of children with ID in terms of the disability type of the children. In the literature, there are studies conducted with different disability groups and different results are observed. In a study conducted with the parents of children with ID or PD, the fathers of children with ID had higher levels of life satisfaction than the mothers (Akandere et al., 2009). Deniz et al. (2009) observed that parents of children with visual impairment, hearing impairment or other disability types had higher levels of life satisfaction than parents of children with Down syndrome/ID. In his study conducted with parents of individuals with ID displaying normal development, Yavuz (2016) found that parents of typically developing individuals had high levels of life satisfaction. It is believed that parents of children with ASD having low levels of life satisfaction according to the results of this study might be because of the characteristics of ASD. Individuals with ASD exhibit more behavioral problems and require more care. Due to characteristics of children with ASD such as the lack of ability to make eye contact and resistance to physical touch, parents are not able to feel the love their children. It is thought that these characteristics negatively affect levels of their life satisfaction. According to Hartley et al. (2016), children with ASD exhibit more behavioral problems compared to other disability groups. For this reason, more psychological problems are observed in these individuals' parents than those of typically developing individuals or individuals in other disability groups.

Resilience levels of mothers were found to be higher than fathers regarding the overall scale results and the Bellicosity, Commitment to Life and Self-Control subdimensions. There were various results in the literature parallel to the results of the present study. In a study conducted by Aysever \& Demirok (2019), there were significant differences in the Bellicosity subdimension of the Family Resilience Assessment Scale. Kumbasar (2016) found significant differences in the Self-Efficacy subdimension of the scale in favor of the mother. On the other hand, Campbell-Sills et al. (2009) and Lee et al. (2009) reported that fathers were more resilient. Kad1 (2016) reported that fathers of individuals with multiple disabilities had higher resilience levels than mothers in the bellicosity subdimension. Moreover, there are also studies reporting that the family resiliency levels do not show a significant difference in terms of the age variable (Kaner et al., 2011; Plump, 2011; Turan, 2017). It is believed that reason of the fact that mothers are more resilient is having high life satisfaction and having a more positive perspective. According to Hastings et al. (2002), mothers accept their children's disabilities easier since they have a more positive outlook.

When the resilience levels of parents were evaluated in terms of the age variable, the resilience levels of young parents were higher in the self-efficacy subdimension. In their studies, Aysever \& Demirok (2019) found that young parents were more resilient in the control subdimension of the scale, Kaner et al. (2011) found that they were more resilient in the self-efficacy and commitment to life subdimensions. Similarly, according to Lee et al. (2009), young parents perceive themselves as being more resilient. On the other hand, there were also studies reporting that resilience levels increased in parallel to the age (Campbell-Sills et al., 2009; Lloyd \& Hastings, 2009). In addition to these, there are also studies reporting that age does not have a significant effect on family resilience levels (Kad1, 2016; Turan, 2017). According to the results of this study, the reason why young parents were observed to be more resilient in the self-efficacy subdimension might be that the young parents were more hopeful since their children were small and affected less by the negative effects of disability.

Parents with high-income levels had high resilience levels in terms of income and the bellicosity, commitment to life and self-control subdimensions of the scale. When the literature was examined, we found results similar to the results of the present study (Bhana \& Bachoo, 201; Campbell-Sills et al., 2009; Greeff \& Walt, 2010; Walsh, 2003; Taşdemir, 2013). However, some studies reported that there is not a relationship between income level and family resilience levels (Kad1, 2016; Kumbasar, 2016; Turan, 2017). According to the study results, high family resilience levels in the subdimensions of the scale show that financial means affect the resilience of the family. This is because parents with high financial means can access services such as necessary information, education, health easier. Accessing these services easier might have a protective effect for parents against stress and depression. According to Kocakaya (2017) and Upadhyaya and Havalappanavar (2008), the child having a disability provides an important contribution to the psychological endurance of the individuals in the family. Similarly, according to Mcconnell et al. (2014) and Upadhyaya and Havalappanavar (2008), resolving the parents' financial difficulties will positively affect their behaviors and mental states.

According to the results of this study, there were no significant differences between the levels of education and family resilience of parents of individuals with disabilities. On the other hand, parents with an undergraduate level education had higher scores than parents with primary level education in the bellicosity subdimension. Similar results were found in the literature. There are studies reporting that levels of education positively affect family resilience levels (Campbell-Sills et al., 2009; Turan, 2017). On the contrary, there are also results reporting that the levels of education 

WITH AUTISM SPECTRUM DISORDER AND INTELLECTUAL DISABILITIES

do not have any effects on family resilience (Kaner et al., 2011; Kumbasar, 2016; Plumb, 2011; Ryan \& Caltabiano, 2009; Taşdemir, 2013). Low levels of education attainment can also be an indicator of having a low-income rate. In this case, it causes the parents to be insufficient in meeting their children's education, health and other needs. Similar results were encountered when the literature was reviewed. According to Moh and Magiati (2012), parents with low levels of education probably have low-income rates. For this reason, they are more vulnerable to stress and depression. On the other hand, families with a high level of education can notice the needs of their children with disabilities in advance and meet their needs. Thus, they will not have stress and depression.

Regarding the disability type, in the overall scale score and the bellicosity, self-efficacy and commitment to life subdimensions of the scale, a significant difference was observed in the parents' resilience levels in favor of parents of children with ID compared to parents of children with ASD. Since a study comparing the resilience levels of parents of children with ID and ASD was not found in the literature, it is harder to make a comprehensive comment. Nevertheless, in a study conducted by Kaner (2004), it was found that parents of children with ID feel more incompetent compared to parents of children with hearing impairment. Kaner et al. (2011) stated that parents of typically developing children perceived themselves as more resilient compared to parents of children with ID. Uğuz et al. (2004) stated that mothers of children with physical disability and ID had more psychological problems than mothers of children with no disabilities. However, there are also studies stating that the disability type does not affect the psychological traits of the parents. Ha et al. (2008) did not observe differences between the stress levels of parents of children with mental health problems and parents of children with developmental disabilities. In a study conducted by Kocakaya (2017), no differences were found between families of individuals with and without severe disabilities. Palanc1 (2018) found that resilience levels of parents of children displaying normal development were high compared to parents of children with disabilities. The reason that resilience levels of parents of children with ID are high according to the results of this study might be because ASD is a part of the severe disability group. Due to being in the severe disability group, the children might exhibit various developmental and behavioral problems in all developmental areas (Huang et al., 2014; Şafak, 2012). These problems might have resulted in families' having more stress and affecting their resilience levels. In a study conducted with parents of children with ASD and Down syndrome and typically developing children, it was reported that the parents of children with ASD had higher stress levels (Dabrowska \& Pisula, 2010; Pottie \& Ingram, 2008).

A positive relationship was found between life satisfaction and family resilience and all subdimensions. The literature review revealed that various studies reported similar conclusions with the results of the present study. The study conducted by Palanc1 (2018) showed that there was a positive correlation between parents of children with ASD and ID, family resilience and life satisfaction. In a study conducted by Bingham (2004), a positive correlation was observed between resilience and life satisfaction in individuals who were mistreated in their childhood. In a study conducted by Openshaw (2011), a strong correlation was observed between family resilience and life satisfaction of parents of individuals with disabilities. Akbar et al. (2014) reported a strong correlation between resilience levels and life satisfaction in nomadic individuals. Palanc1 (2018) observed a positive correlation between family resilience and life satisfaction in a study conducted with parents of individuals with disabilities. Demiray (2019) observed a positive relationship between family quality of life in parents of children with special needs. Additionally, there was a weak positive relationship between quality of life and one of the subdimensions of the family quality of life scale, "bellicosity", a weak positive relationship with "self-efficacy", and a weak positive relationship with "commitment to life". In other words, when the levels of bellicosity, self-efficacy and commitment to life of the family increased, an increase was observed in quality of life of families.

This study was limited to Bursa and Izmir provinces and the participating parents. This study can be conducted in different provinces with different disability groups and parents of children displaying normal development using combined methods. Furthermore, programs that support parents' levels of life satisfaction and resilience can be organized considering the results of this study. 